\title{
POTESTAS NOCENDI W ŚWIETLE KOMENTARZY ŚW. AUGUSTYNA DO KSIĘGI HIOBA 1-2
}

Biblijna opowieść o Hiobie rozgrywa się na dwóch wzajemnie uzupełniających się płaszczyznach. Pierwsza z nich to historia głównego bohatera, który będąc bogatym człowiekiem, traci cały majątek i wszystkie swoje dzieci, a sam musi zmagać się z chorobą i cierpieniem, nie znajdując zrozumienia ani ze strony przyjaciół, ani nawet pozostałej przy życiu żony. Są to zatem dzieje przygniecionego cierpieniem człowieka, które mogą być dostępne ludzkiemu doświadczeniu i ułożone w ciąg następujących po sobie i powiązanych ze sobą przyczynowo faktów. Druga płaszczyzna zaś ukazuje wydarzenia rozgrywające się równolegle, chociaż na głębszym, bo duchowym poziomie, opisane przez autora natchnionego w formie dialogu diabła z Bogiem. One to wpływają na przebieg wypadków na pierwszej scenie oraz je wyjaśniają. Wobec tego cierpienie Hioba okazuje się więc być skutkiem działania diabelskiego, dopuszczonego na niego przez Boga ${ }^{1}$.

Pierwsza płaszczyzna wprowadza czytelnika w wielkie pytanie o „misterium niezawinionego cierpienia"2, ukazując zmagania Hioba z pokusami i jego walkę o wierność Bogu oraz stawiając pytania o sens i konieczność znoszenia rozmaitych nieszczęść. Te zagadnienia wyznaczają główny nurt rozważań i komentarzy dotyczących Księgi Hioba, jakie znaleźć można najpierw u Ojców Kościoła, a następnie u współczesnych badaczy ich myśli³ .

Historia Hioba może być jednak bardziej zrozumiała dopiero wówczas, gdy w większym stopniu uwzględni się rolę, jaką odgrywają w niej wydarzenia

\footnotetext{
* Ks. dr Mariusz Terka - wykładowca patrologii w Wyższym Instytucie Teologicznym w Częstochowie; e-mail: mariuszterka0@op.pl.

${ }^{1}$ Por. The Oxford Guide to the historical Reception of Augustine, ed. K. Pollmann, vol. 1, Oxford 2013, 155-156; G. Mura, Introduzione, w: Sant'Agostino, Opere esegetiche, ed. G. Mura - V. Tarulli, NBA 10/3, Roma 1999, 27-28; K.B. Steinhauser, Adnotationes in Job, w: Agostino Dizionario Enciclopedico (=ADE), ed. A. Fitzgerald, ed. italiana L. Alici - A. Pieretti, Roma 2007, 114-115.

2 Por. M. Jóźwiak, „Komentarz do historii Hioba” Filipa Prezbitera a epistoma tego dzieła. Przyczynek do badań porównawczych nad tymi tekstami, VoxP 34 (2014) t. 62, 185.

${ }^{3} \mathrm{Na}$ temat komentarzy Ojców Kościoła do Księgi Hioba zob. M.C. Paczkowski, Reinterpretacja postaci Hioba w starożytnym monastycyzmie chrześcijańskim, BPTh 6 (2013) 179-203; L. Nieścior, Cierpienie sprawiedliwego w Komentarzu do Księgi Hioba św. Jana Chryzostoma, WPT 16 (2008) nr 1, 211-230; M. Brugarolas, Księga Hioba wedtug Grzegorza z Nyssy, thum. A. Machowski, BPTh 6 (2013) 149-165.
} 
ukazane na drugiej płaszczyźnie. Wydaje się bowiem, że przedstawione w Piśmie Świętym duchowe tło dziejów Hioba, wyjaśniając jego losy, samo domaga się zrozumienia i interpretacji. Mimo wszystko ciagle nie jest bowiem rzeczą jasną zarówno sama przyczyna, jak i cel zgody Boga na cierpienia Hioba, ani też pozwolenie na szkodzenie (potestas nocendi), którego udziela Wszechmocny diabłu. Wyjaśnienia domaga się zatem przede wszystkim pytanie o warunki możliwości wydarzeń rozgrywających się na duchowej płaszczyźnie historii Hioba.

W tym kierunku zmierzają też komentarze patrystyczne, łącząc w sobie te dwie perspektywy i szukając dla nich wyjaśnienia w ich wzajemnym uwarunkowaniu. Chociaż więc podejmowana analiza nie może abstrahować od sytuacji wystawionego na cierpienia i pokusy Hioba, gdyż to ona stanowi kontekst historii rozgrywanej na płaszczyźnie duchowej i w pewnym stopniu o niej decyduje, to jednak szczególnym przedmiotem jej zainteresowania winno być przede wszystkim to, co dzieje się w przestrzeni zakreślonej przez duchowe, choć przecież nierównomierne, relacje, jakie zachodzą pomiędzy Bogiem, diabłem i Hiobem. One zatem wyznaczają dla podejmowanego zagadnienia pole badawcze, które obejmuje swym zasięgiem „przestrzeń” wzajemnego oddziaływania rzeczywistości empirycznej i duchowej.

$\mathrm{Z}$ racji tak postawionych pytań analizę interpretacji patrystycznych należy ograniczyć do tych, które odnoszą się do dwóch pierwszych rozdziałów Księgi Hioba. W nich bowiem znajduje swe wyjaśnienie zarówno władza diabła nad bohaterem - przyczyna wszystkich nieszczęść, które go spotykają, jak i udzielona już na początku jego odpowiedź na dotykające go cierpienie.

Na przewodnika w poszukiwaniu odpowiedzi na te kwestie został wybrany św. Augustyn, gdyż - jak się wydaje - w jego myśli można znaleźć interesujące rozwiązania postawionego problemu, który często zajmuje jego uwagę. Pole podjętych poszukiwań wyznaczają zaś wypowiedzi biskupa Hippony dotyczące opisywanych w Księdze Hioba wydarzeń, a zawarte zarówno w jego Adnotationes in Job, jak i w licznych komentarzach oraz nawiązaniach do postaci głównego bohatera rozsianych w dziełach Hippończyka. Ukazują one badane zagadnienie $\mathrm{z}$ wielu różnych perspektyw, stąd też rzeczą konieczną będzie, by analiza podążająca za myślą św. Augustyna, niejednokrotnie zataczała swoiste koło hermeneutyczne, wracając, choć na głębszym poziomie, do tych samych wydarzeń i szukając ich sensu.

1. Logika podejrzeń. Biblijna historia Hioba rozpoczyna się od opisu szczęśliwego i dostatniego życia człowieka otoczonego przez najbliższych, troszczącego się jedynie o to, by we wszystkim podobać się Bogu. Tę właśnie pobożność akcentuje szczególnie św. Augustyn, gdy rozpoczyna swój komentarz do dziejów Hioba, podkreślając, że składane przez niego ofiary oczyszczenia za synów, są wyrazem jego miłości do nich oraz troski o ich czystość 
przed Bogiem 4 . Relacja Hioba względem Boga jest zatem dla Hippończyka osią, wokół której buduje on swoją interpretację jego losów oraz punktem wyjścia do jej zrozumienia. Dlatego też najczęściej pomija on zupełnie biblijny opis bogactwa i szczęśliwego życia Hioba, a utrata przez niego majątku, rodziny oraz zdrowia, sa jedynie wzmiankowane w kontekście postawy, jaką przyjął bohater wobec trudnej dla niego sytuacji cierpienia ${ }^{5}$. Tym bowiem, co szczególnie interesuje biskupa Hippony w tej części narracji o Hiobie, jest to wszystko, co dzieje się na drugiej scenie tego dramatu, czyli podczas rozmowy diabła z Bogiem.

Augustyńska interpretacja tego dialogu nie tylko odsłania uniwersalną prawdę o sposobie postępowania złego ducha względem każdego kuszonego człowieka, które często stoi u podstaw różnego rodzaju cierpień i utrapień, jakie spadają na niego w ziemskim życiu ${ }^{6}$, lecz także zawiera wyjaśnienie tego, co dzieje się na drugiej scenie dramatu. Biskup Hippony, tłumacząc bowiem rozstrzygający o przyszłych wydarzeniach w życiu Hioba dialog diabła z Bogiem, zauważa, że punktem wyjścia dla złego ducha i jego głównym argumentem w rozmowie jest skierowane pod adresem Hioba podejrzenie. Działanie diabelskie rozpoczyna się od zakwestionowania sprawiedliwości człowieka, którego Bóg stawia za wzór swego sługi, zaś żywiołem, w którym się ono porusza, jest logika podejrzeń. To ona też znajduje się u źródeł wszelkich nieszczęść, jakie spadają na Hioba za przyczyną złego ducha. Dlatego też wydaje się, że bliższe wyjaśnienie jej funkcjonowania pozwoli lepiej zrozumieć naturę analizowanej potestas nocendi.

Hippończyk wyjaśnia istotę logiki podejrzeń posługując się analogią zaczerpniętą z relacji międzyludzkich. Zauważa bowiem, że człowiek, który swym sercem przylgnął do marności rzeczy doczesnych, takich jak: ludzkie pochwały, pieniądze, pożywienie, czy ubrania lub nawet do grzechu, spełnia dobre uczynki oraz oddaje cześć Bogu ze względu na to, by tych spraw nie stracić. Troska o nie wypełnia bowiem jego serce ${ }^{7}$. Ponieważ jednak widzi takie nastawienie umysłu u siebie, a nie posiada dostępu do serc innych ludzi, wobec tego podejrzewa ich o takie same motywy ich pobożnego i sprawiedliwego postępowania. Człowiek jest bowiem skłonny podejrzewać u innych to, co sam przeżywa ${ }^{8}$.

W sposób analogiczny - zdaniem św. Augustyna - postępuje diabeł, który podejrzewa (suspicor) sprawiedliwego Hioba o to, że za jego dobrymi czynami

${ }^{4}$ Por. Augustinus, Adnotationes in Job 1, NBA 10/3, 42.

${ }^{5}$ Por. tamże.

${ }^{6}$ Por. Steinhauser, Adnotationes in Job, ADE, s. 115.

${ }^{7}$ Por. M. Terka, Źli chrześcijanie w Kościele w świetle nauczania św. Augustyna, VoxP 33 (2013) t. 60, 418-429.

${ }^{8}$ Por. Augustinus, Enarrationes in Ps. 118 (12), 4, ed. T. Mariucci - V. Tarulli, NBA 27, Roma 1976, 1214, tłum. J. Sulowski, PSP 41, Warszawa 1986, 259-260; tenże, De civitate Dei XIX 5, ed. B. Dombard - A. Kalb, CCL 48, Turnholti 1955, 669, thum. W. Kubicki: Św. Augustyn, Państwo Boże, Kęty 2002, 769. 
i pobożnością ukrywają się zupełnie inne, interesowne motywy9 . Są one tylko skrywane za zasłoną dobrych uczynków i głęboko utajone w sercu bohatera tej opowieści biblijnej. Chodzi więc o to, by je zdemaskować, czyli ukazać fałszywość jego postawy moralno-religijnej. Hippończyk podkreśla bowiem, że powodem prośby skierowanej przez diabła do Boga o pozwolenie doświadczenia Hioba jest ujawnienie tego, że służy on swemu Stwórcy jedynie ze względu na posiadane przez siebie dobra materialne i szczęśliwą rodzinę ${ }^{10}$. Logika podejrzeń podpowiada zatem, że chociaż Hiob na zewnątrz wydaje się być człowiekiem oddanym we wszystkim Bogu, to tak naprawdę jego serce bardziej przylgnęło do marności światowych i im tak naprawdę służy.

Podejrzenie odwołuje się więc do tego, co nie jest widoczne dla wszystkich, zaś u jego podstaw tkwi przeświadczenie, że ta ukryta rzeczywistość nie tylko istnieje, ale jest tym, co istnieje naprawdę, a będąc fundamentem tego wszystkiego, co ukazuje się zwyczajnemu poznaniu, determinuje wszystkie ludzkie czyny. Skoro jednak podejrzenie odnosi się do jakiejś ukrytej sfery, to znaczy, że musi być ona skryta także dla samego podejrzewającego. Stąd też podejrzenie - jak naucza biskup Hippony - nie jest jeszcze wiedza, gdyż znając prawdę nie można, ani nie trzeba niczego podejrzewać. Wymaga więc ono dla swego zaistnienia i utrzymania się jakiejś niewiedzy odnośnie do przedmiotu, ku któremu jest skierowane. Diabeł bowiem nie posiada dostępu do serca Hioba i dlatego nie wie, jakie są prawdziwe motywy jego pobożnego postępowania $^{11}$. Św. Augustyn zauważa jednak, że ta niewiedza diabła wcale mu nie przeszkadza, a wręcz umożliwia zaistnienie podejrzenia. Chociaż bowiem zły duch nie wie, czy Hiob oddaje cześć Bogu ze względu na otrzymane od Niego bogactwa lub nadzieje na ich zachowanie, to nie wie przecież także tego - jak podkreśla Hippończyk - czy jego pobożność jest rzeczywiście bezinteresowna ${ }^{12}$. Okazuje się więc, że do tego, by mogło zaistnieć podejrzenie wobec Hioba, nie jest konieczna pewność co do jego interesowności, lecz wystarczy podważenie czystości jego intencji oraz motywów jego postępowania. To na tym właśnie skupia się owa demaskująca niewiedza ${ }^{13}$.

Podejrzenie karmi się więc pewnego rodzaju zakwestionowaniem zewnętrznych przejawów pobożności oraz intencji dobrych czynów. Pod względem formalnym przyjmuje ono postać negacji tego, co pozytywne w swym zewnętrznym przejawie. Oznacza to, że podejrzenie, rozumiane jako demaskowanie ukrytej za dającymi się zaobserwować pozorami rzeczywistości

\footnotetext{
${ }^{9}$ Por. tenże, Adnotationes in Job 1, NBA 10/3, 42; tenże, Enarrationes in Ps. 118 (12), 4, NBA 27, 1214, PSP 41, 260.

${ }^{10}$ Por. tenże, Enarrationes in Ps. 118 (12), 4, NBA 27, 1214, PSP 41, 260; tenże, De civitate Dei XIX 13, CCL 48, 679-680, thum. Kubicki, s. 780-781.

${ }^{11}$ Por. tenże, Enarrationes in Ps. 55, 20, ed. V. Tarulli, NBA 26, Roma 1970, 158-160, thum. J. Sulowski, PSP 38, Warszawa 1986, 362-363.

${ }^{12}$ Por. tamże.

${ }^{13}$ Por. tenże, Sermo 9, 4, 4, PL 38, 569; tenże, Enarrationes in Ps. 55, 20, NBA 26, 158-160, PSP 38, 362-363.
} 
prawdy, zawiera w sobie zarówno zakwestionowanie tego, co jest zauważalne, jak i dążenie do odsłaniania tego, co niewidoczne, a co oceniane jest w kategorii moralnego zła ${ }^{14}$. Dlatego też podejrzenie usiłuje ukazać Hioba jako człowieka interesownego, służącego Bogu wyłącznie ze względu na korzyści materialne, twierdząc, że to właśnie jest pełną prawdą o nim.

Skoro zatem podejrzenie objawia się jako demaskujące osłanianie ukrytego zła, a jednocześnie bazuje przecież na niewiedzy i braku pewności odnośnie do postawionych tez, to oznacza, że ze swej natury jest ono oskarżeniem ( $a c$ cusatio ${ }^{15}$. W takich właśnie kategoriach opisuje św. Augustyn działanie diabła względem Hioba. Zły duch zatem oskarża go (accusare), zarzuca (obicere) mu ukryty grzech ${ }^{16}$, obrzuca go oszczerstwem (calumnia) ${ }^{17}$, kusi skrycie (oculte tentare $)^{18}$, podejrzewa i znieważa (suspicor, maledictio) $)^{19}$, zastawia na niego sidła (laquere) jak przebiegły nieprzyjaciel (versutus inimicus) ${ }^{20}$, który w swej przewrotności (malitia diaboli) $)^{21}$ zazdrości świętemu (invidere sancto) ${ }^{22}$.

Dla biskupa Hippony owa zazdrość jest głównym motywem działania diabelskiego oraz siłą napędzającą podejrzliwe oskarżenie wysuwane wobec Hioba, thumacząc je i nadając mu określone kierunki praktycznej realizacji ${ }^{23}$. W świetle użytych przez Hippończyka czasowników przedstawiających działanie złego ducha można zauważyć, że opiera się ono przede wszystkim na kłamstwie oraz chęci szkodzenia (malevolentia). Te dwa elementy są ze sobą powiązane i wzajemnie z siebie wynikają. Św. Augustyn zauważa bowiem, że skoro diabeł zazdrości Hiobowi sprawiedliwości, to sugerując jego ukryty grzech, posługuje się kłamstwem i oszczerstwem względem niego. Wydaje się, że bazuje ono właśnie na owej niewiedzy, gdyż zły duch nie zna przecież serca ludzkiego i w związku z tym nie posiada żadnej wiedzy świadczącej

${ }^{14}$ Por. tenże, Enarrationes in PS. 118 (12), 4, NBA 27, 1214, PSP 41, 260; tenże Sermo 9, 4, 4, PL 38, 569.

${ }^{15}$ Por. tenże, Enarrationes in Ps. 34 (1), 7, ed. A. Corticelli, NBA 25, Roma 1967, 677, thum. J. Sulowski, PSP 37, Warszawa 1986, 355; tenże, Adnotationes in Job 1, NBA 10/3, 42; tenże, Sermo 12, 3, ed. C. Lambot, CCL 41, Turnholti 1961, 167.

${ }^{16}$ Por. tenże, Enarrationes in Ps. 55, 20, NBA 26, 158, PSP 38, 363; S. Kowalczyk, Człowiek i Bóg w nauce św. Augustyna, Lublin 2007, 139.

${ }^{17}$ Por. Augustinus Sermo 12, 2, CCL 41, 165; tamże 15, 6, CCL 41, 198; tamże 9, 4, 4, PL 38, 569; tenże, Enarrationes in Ps. 118 (26), 4, NBA 27, 1348, PSP 41, 319.

${ }^{18}$ Por. tenże, Enarrationes in Ps. 90 (1), 2, NBA 27, 132, tłum. J. Sulowski, PSP 40, Warszawa 1986, 175.

${ }^{19}$ Por. tenże, Adnotationes in Job 1, NBA 10/3, 42.

${ }^{20}$ Por. tenże, Enarrationes in Ps. 120, 11, NBA 27, 1448, PSP 41, 366.

${ }^{21}$ Por. tamże 77, 28, NBA 26, 1046, thum. J. Sulowski, PSP 39, Warszawa 1986, 396.

${ }^{22}$ Por. tamże 34 (1), 7, NBA 25, 677, PSP 37, 355; tenże, Sermo 12, 8, CCL 41, 170; tenże, Enarrationes in Ps. 103 (4), 7, NBA 27, 758-760, PSP 41, 62-63; tenże, De divinatione daemonum 6, 10, PL 40, 586-587.

${ }^{23}$ Por. tenże, De civitate Dei VIII 22, ed. B. Dombard - A. Kalb, CCL 47, Turnholti 1955, 239, thum. Kubicki, s. 315. 
o interesowności postępowania Hioba ${ }^{24}$. To zatem, co umożliwia podejrzenie sprawia więc równocześnie, że jest ono kłamstwem.

Z kolei podstęp, którego dopuszcza się diabeł, sugerując Bogu nieszczerość intencji Hioba, łączy ze sobą kłamstwo z chęcią szkodzenia. Biskup Hippony podkreśla bowiem, że zły duch po to wysuwa podejrzenie względem Hioba, by skłonić go do grzechu. Te wszystkie doświadczenia, jakie miały na niego spaść, sprowadza diabeł na niego, by przekonać się o prawdziwości swego podejrzenia ${ }^{25}$, ale również dlatego, że spodziewa się jego upadku ${ }^{26}$.

Przedstawione zależności ukazują zatem pewien mechanizm, w ramach którego one funkcjonują. Otóż wydaje się, że działająca w żywiole zazdrości chęć szkodzenia uzasadnia kłamliwe podejrzenie, zaś oparte na kłamstwie demaskujące oskarżenie odnośnie do ukrytego zła, wydaje się udzielać motywacji do podejmowania prób zaszkodzenia Hiobowi. Św. Augustyn opisuje to zjawisko, mówiąc o działaniu służących diabłu demonów:

„A jacy to będą twoi panowie? Zazdrośni w stosunku do ciebie. Muszą ci zazdrościć wolności, zawsze będą starali się ciebie posiąść, zawsze takim mieć, żeby mogli ze sobą pociągnąć. Jest to jakaś swoista złośliwość i przewrotność szkodzenia, będąca cechą tych złych duchów. Cieszą się z ludzkiego nieszczęścia. Pasą się tym, że nas oszukali i z naszego uwiedzenia. A czego szukają? Nie tych, nad którymi będą panować na wieki, ale z którymi będą na wieki potępieni" 27 .

Owo kuszenie, na które zostaje wystawiony Hiob, jest zatem jakąś próbą przeniknięcia diabła do serca (penetrare in cor) doświadczanego przez niego człowieka i zawładnięcia nim ${ }^{28}$. Temu celowi - jak podkreśla biskup Hippony - mają służyć wszystkie nieszczęścia, jakie sprowadza diabeł na sprawiedliwego Hioba ${ }^{29}$. Podejrzliwa zazdrość usiłuje zatem zniszczyć sprawiedliwość i świętość w człowieku. W konsekwencji oznacza to, że zły duch chce doprowadzić do tego, o co podejrzewa Hioba i oskarża go o to, co jest celem jego własnego działania.

Należy jednak zauważyć, że oskarżenie podejrzewające ukrytą winę, kieruje się nie tylko ku Hiobowi, lecz także jest adresowane w stronę Boga. On bowiem jest tym, wobec kogo diabeł kieruje swoje domysły. Dla rozważanego

${ }^{24}$ Por. tenże, Enarrationes in Ps. 55, 20, NBA 26, 158, PSP 38, 362-363; tamże 103 (4), 7, NBA 27, 760, PSP 41, 63.

${ }^{25}$ Por. tamże 118 (12), 4, NBA 27, 1214, PSP 41, 260.

${ }^{26}$ Por. tamże 103 (4), 7, NBA 27, 760, PSP 41, 63.

${ }^{27}$ Tamże 96, 11, NBA 27, 380: „Et qui erunt domini tui? Invidi tui: libertati tuae necesse est invideant, semper te velint possidere, semper talem facere, qualem possint secum trahere. Est enim insita malevolentia quaedam et pernicies nocendi istis malis spiritibus: gaudent de malo hominum; et de fallacia nostra, si nos fefellerint, pascuntur. Et quid quaerunt? Non quibus in aeternum dominentur, sed cum quibus in aeternum damnentur", PSP 40, 288-289.

${ }^{28}$ Por. tamże 103 (4), 7, NBA 27, 760, PSP 41, 63; tenże, Sermo 12, 6, CCL 41, 169.

${ }^{29}$ Por. tenże, Enarrationes in Ps. 103 (4), 7, NBA 27, 760, PSP 41, 63. 
zagadnienia ma to pewne konsekwencje, które wskazują na to, iż nie można zrozumieć istoty owej zazdrosnej chęci szkodzenia, realizującej się wewnątrz logiki podejrzeń, odnosząc ją tylko do relacji diabeł - Hiob, lecz należy ją umieścić również w stosunku diabeł - Bóg, a następnie także we wzajemnej relacji Boga i Hioba. Pozwoli to głębiej ująć naturę szkodliwego działania złego ducha, a także określić jego granice i poznać przyczyny. Wydaje się bowiem, że wyjaśnienie tego zagadnienia znajduje się w punkcie leżącym na przecięciu tych trzech perspektyw.

2. Bóg źródłem władzy szkodzenia. Św. Augustyn rozróżnia chęć szkodzenia (malevolentia, voluntas nocendi) ${ }^{30}$, którą okazuje diabeł i jego demony, od władzy szkodzenia (potestas nocendi) rozumianej jako możliwość zrealizowania owej chęci. Dotąd bowiem pozostaje ona dla złego ducha jedynie jakimś pragnieniem inspirowanym zazdrosną podejrzliwościa, dokąd nie otrzyma on zdolności (potestas) do działania ${ }^{31}$. Teza ta domaga się jednak szerszego uzasadnienia, gdyż takie rozróżnienie nie wyjaśnia jeszcze natury potestas nocendi, a wręcz domaga się odpowiedzi na pytanie o jej źródło.

Wydaje się, że Hippończyk rozważa to zagadnienie głównie w perspektywie zakreślonej przez obszar dobra i zła. Zauważa bowiem, że diabeł posiada jakiś rodzaj władzy nad światem rozumianym w kategoriach aksjologicznych, tzn. jako królestwo grzechu, zła oraz ciemności ${ }^{32}$ i dlatego jest określany jego królem i ojcem ${ }^{33}$, albo też ,księciem tego świata” (princeps huius mundi) ${ }^{34}$. Św. Augustyn porównując za Pismem Świętym świat do wielkiego morza, pisze o diable:

${ }^{30}$ Por. tenże, De diversis quaestionibus ad Simplicianum II 1, 4, PL 40, 131-132, tenże, Enarrationes in Ps. 29 (2), 6, NBA 25, 412, PSP 37, 224.

${ }^{31}$ Por. tenże, Adnotationes in Job 1, NBA 10/3, 42; tenże, De sermone Domini in monte II 9, 34, PL 34, 1284; tenże, Enarrationes in Ps. 29 (2), 6, NBA 25, 412, PSP 37, 224; tenże, Sermo 12, 2 , CCL 41, 166; tenże, De civitate Dei XI 17, CCL 48, 336-337, thum. Kubicki, s. 421; tenże, Epistula 130, 14, 26, PL 33, 504-505; F van Fleteren, Diavolo, ADE, s. 555.

32 Por. Augustinus, Enarrationes in Ps. 141, 15, NBA 28, 610-612, thum. J. Sulowski, PSP 42, Warszawa 1986, 245-246; tamże 119, 7, NBA 27, 1420-1422, PSP 41, 352-353; tenże, In Iohannis evangelium tractatus 2, 11, ed. R. Willems, CCL 36, Turnholti 1954, 17, tłum. W. Szołdrski W. Kania: Św. Augustyn, Homilie na ewangelię św. Jana, w: Św. Augustyn, Homilie na Ewangelie i Pierwszy list św. Jana, PSP 15/1, Warszawa 1977, 47-48; tenże, De diversis quaestionibus ad Simplicianum II 3, 1, PL 40, 142; M.T. Clark, Mondo, ADE, s. 964-966. Zob. Terka, , Corpus diaboli”, czyli duchowe podtoże prześladowań Kościoła w świetle „Enarrationes in Psalmos ” św. Augustyna, w: Być w sercu Kościoła. Księga jubileuszowa z okazji 25 lecia pracy naukowej ks. dr. hab. Mariana Dudy, red. S. Jasionek, Częstochowa 2014, 344-348.

${ }^{33}$ Por. Augustinus, Enarrationes in PS. 26 (2), 18, NBA 25, 380, PSP 37, 210; tenże, Contra Iulianum VI 2, 3, PL 44, 822, tłum. W. Eborowicz: Św. Augustyn, Przeciw Julianowi, PSP 29/1, Warszawa 1977, 147-148.

${ }^{34}$ Por. tenże, Sermo 12, 2, CCL 41, 166; tenże, Enarrationes in Ps. 71, 7, NBA 26, 798, PSP 39 , 275; C. Bianchi - Ch. Müller, Diabolus, w: Augustinus-Lexicon, hrsg. C. Mayer - A.E.J. Grotte, vol. 2, Basel 1996-2002, 384; Fleteren, Diavolo, ADE, s. 555. 
„On to skutkiem swojego grzechu, spadając ze wzniosłego mieszkania niebieskiego i z anioła stawszy się diabłem, znalazł swoje określone miejsce na tym morzu wielkim i przestronnym. To, co uznajesz za jego królestwo, jest jego więzieniem"35.

Obecność i królowanie diabła w świecie nie jest więc dla niego czymś naturalnym, czyli przynależnym mu z natury, lecz zostaje określone przez biskupa Hippony jako upadek, zaś świat jako jego więzienie. Dlatego też św. Augustyn stwierdza, że zły duch nie tyle otrzymał władzę nad światem, ile ją właściwie stracił, gdy poniósł karę za swój grzech, a wielkość jego upadku należy mierzyć nie miara jego obecnych działań wobec ludzi, lecz wspaniałością anielskiej siedziby w niebie, którą utraci ${ }^{36}$. Św. Augustyn podkreśla przy tym, że ten upadek diabła jest podstawową przyczyną zazdrości, jaką żywi wobec człowieka, a w związku z tym stoi on także u podstaw woli szkodzenia ${ }^{37}$.

Oznacza to, że zły duch posiada pewien rodzaj władzy, lecz sam nie jest jej źródłem. Z wypowiedzi biskupa Hippony można także wywnioskować, że ta moc dotyczy wyłącznie tych, którzy przynależą do jego królestwa, czyli złych mieszkańców jego świata ${ }^{38}$. Inaczej zaś ma się sprawa z ludźmi sprawiedliwymi, do których niewatpliwie zalicza św. Augustyn Hioba. Skoro bowiem zły duch usiłuje go zniszczyć, zastawiając na niego sidła swych pokus, a jednocześnie kieruje przeciwko niemu oskarżenie o ukryty grzech, z którym występuje wobec Boga, to dla biskupa Hippony znaczy to tyle, że sam z siebie nie posiada on władzy nad człowiekiem sprawiedliwym ${ }^{39}$. Wola szkodzenia pochodzi niewattpliwie od niego i jest jego wina, lecz nie ma on żadnych możliwości wyrządzenia jakiegokolwiek zła człowiekowi sprawiedliwemu. Dlatego też, by mogła zostać zrealizowana jego chęć szkodzenia, musi on otrzymać moc działania, która może pochodzić tylko z zewnątrz, tzn. od tego, do kogo z natury należy najwyższa władza (summa potestas), czyli od Boga ${ }^{40}$. To właśnie jest powodem, dla którego - jak zauważa Hippończyk - w opowieści biblijnej diabeł przychodzi do Boga oskarżając przed Nim Hioba. Demaskująca

${ }^{35}$ Augustinus, Enarrationes in Ps. 103 (4), 7, NBA 27, 758: „Ipse cadens peccato suo de sublimi habitatione coelorum, et ex angelo factus diabolus, accepit quemdam locum suum in hoc mari magno et spatioso. Regnum eius quod putas, carcer eius est”, PSP 41, 62; tenże, De divinatione daemonum 3, 7, PL 40, 584; F. van der Meer, Augustinus der Seelsorgen. Leben und Wirken eines Kirchenväters, Köln 1951, 96-97.

${ }^{36}$ Por. Augustinus, Enarrationes in PS. 103 (4), 9, NBA 27, 766, PSP 41, 66; tenże, De civitate Dei XIV 11, CCL 48, 431-432, thum. Kubicki, s. 526-527; tenże, De divinatione daemonum 6, 10 , PL 40, 586-587; Bianchi - Müller, Diabolus, w: Augustinus-Lexicon, vol. 2, s. 385.

${ }^{37}$ Por. Augustinus, De civitate Dei XIV 11, CCL 48, 432, thum. Kubicki, s. 527; S. Isetta, Libro XI del „De civitate Dei”, w: Lettura del „De civitate Dei” libri XI-XVI, Roma 2009 = SEA 115 (2009) 31-32.

${ }^{38}$ Terka, ,, Corpus diaboli”, s. 347-357.

${ }^{39}$ Por. Augustinus, Enarrationes in Ps. 103 (4), 7, NBA 27, 760, PSP 41, 62; tamże 100, 12, NBA 27, 502, PSP 40, 344.

${ }^{40}$ Por. tamże 34 (1), 7, NBA 25, 677, PSP 37, 355. 
podejrzliwość złego ducha ma być uzasadnieniem dla udzielenia mu władzy szkodzenia (potestas nocendi) wobec Hioba, a w konsekwencji doprowadzenia go do upadku i złorzeczenia Bogu. Św. Augustyn naucza o tym w następujących słowach:

„Złość ludzka może też posiadać własną żądzę szkodzenia. Ale władzy nie posiada, o ile On nie zezwoli. «Nie masz bowiem władzy, jak tylko od Boga» (Rz 13, 1), tak stanowczo stwierdza Apostoł. Nie powiedział: Nie ma żądzy, jak tylko od Boga. Żądza bowiem jest zła, nie jest ona od Boga. Ale że owa zła żądza nikomu nie szkodzi, dokąd On nie zezwoli. [...] Dlatego Bóg-Człowiek stojąc przed człowiekiem rzekł: «Nie miałbyś nade mną żadnej władzy, gdyby ci nie została z góry dana» $(\mathrm{J} 19,11)$. Co to oznacza? Czy tylko człowiek nie posiada władzy, o ile jej nie otrzyma z góry? A sam diabeł, czy ośmieliłby się choćby jedną owieczkę zabrać świętemu mężowi Jobowi, zanim nie powiedział: «Wyciagnij rękę», czyli daj władzę? Chciał, ale On nie zezwolił. Kiedy On zezwolił, dopiero wówczas mógł. Zatem nie mógł tak długo, dopóki on nie zezwolił"41.

Św. Augustyn zauważa w tym kontekście oczywisty na pozór fakt, iż Bóg zezwalając na szkodzenie Hiobowi, wysłuchuje w rzeczywistości prośby diabła. Wrażenie pewnego rodzaju paradoksu, jakie można odnieść w związku z takim postępowaniem Boga, pogłębia Hippończyk poprzez odniesienie się do Pisma Świętego, w którym opisane są analogiczne sytuacje. Już bowiem Chrystus, wyrzucając demony z człowieka opętanego, spełnia ich prośbę i pozwala im wejść w świnie (por. Mt 8,31), nie wysłuchuje natomiast własnego Apostoła, gdy ten prosi o oddalenie pewnych utrapień nazywanych przez niego ościeniem ciała, z którymi musi się zmagać (por. 2Kor 12, 9) ${ }^{42}$. Teolog

${ }^{41}$ Tamże 32 (3), 12, NBA 25, 592: „Et malitia hominum cupiditatem nocendi potest habere propriam: potestatem autem si ille non dat, non habet. Non est enim potestas nisi a Deo: definitiva sententia Apostoli est. Non dixit: Non est cupiditas nisi a Deo. Est enim mala cupiditas, quae non est a Deo: sed quia ipsa mala cupiditas nulli nocet, si ille non permittat. [...] Unde Deus homo stans ante hominem: Non haberes, inquit, in me potestatem, nisi data fuisset tibi desuper. Ille iudicabat, ille docebat: cum iudicabatur, docebat, ut iudicaret quos docuerat: Non haberes, inquit, in me potestatem, nisi esset data tibi desuper. Quid hoc? Homo tantum non habet potestatem, nisi cum acceperit desuper? Quid ipse diabolus, ausus est vel unam oviculam tollere viro sancto Iob, nisi prius diceret: Mitte manum tuam, hoc est, da potestatem? Ille volebat, sed ille non sinebat; quando ille permisit, ille potuit: non ergo ille potuit, sed qui permisit", PSP 37, 312. Owo zezwolenie, czyli nadanie mocy diabelskiej woli szkodzenia jest wyrażone w Biblii poprzez gest wyciągniętej ręki, o który dwukrotnie prosi Boga zły duch (por. Hi 1, 11; 2, 5). Św. Augustyn (Enarrationes in Ps. 120, 11, NBA 27, 1448-1450, PSP 41, 365-366) zauważa bowiem, że przez ten symbol określona została potęga Boża. Por. tenże, De Genesi ad litteram XI 4, 6, ed. L.Carrozzi, NBA 9/2, Roma 1989, 564, thum. J. Sulowski: Św. Augustyn, Komentarz stowny do Księgi Rodzaju, w: Św. Augustyn, Pisma egzegetyczne przeciw manichejczykom, PSP 25, Warszawa 1980, 320-321.

${ }^{42}$ Por. tenże, In epistulam Iohannis ad Parthos tractatus decem 6, 7, ed. G. Madurini - L. Muscolino, NBA 24/2, Roma 1968, 1756-1758, thum. W. Szołdrski - W. Kania: Św. Augustyn, Homilie na Pierwszy list św. Jana, w: Św. Augustyn, Homilie na Ewangelie i Pierwszy list św. Jana, PSP 
z Hippony wyraża tę samą myśl w sposób jeszcze bardziej dosadny: otóż Bóg zdaje się nie słuchać modlitwy swego ucznia, który dla Niego poświęca swe życie i cierpi, ale pozwala sprowokować się (provocare) diabłu, swemu nieprzyjacielowi, choć ten pragnie zniszczyć Jego sługę ${ }^{43}$. Biskup Hippony, nawiązując do słów Hioba, w których zgadza się on ze swymi nieszczęściami, wysnuwa z tego faktu następujący wniosek:

„Cokolwiek takiemu się przytrafi, powiada: «Pan dał, Pan wziął». Oto serce prawe: «Jak się Panu spodobało, tak się stało, niech imię Pańskie będzie błogosławione (Hi 1, 21)». Kto zabrał? Co zabrał? Komu zabrał? Kiedy zabrał? Niech imię Pańskie będzie błogosławione. I nie mówi: Pan dał, diabeł zabrał. Rozważcie to, bracia kochani, abyście przypadkiem nie mówili: Diabeł mi to uczynił. Wprost do swojego Boga odnoś własne bicze, bo diabeł niczego ci nie zrobił, gdyby nie przyzwolił ten, który z góry posiada władzę karania lub doświadczania" ${ }^{\prime 4}$.

Jego zdaniem należy zatem obciążyć odpowiedzialnością za to wszystko, co przydarzyło się Hiobowi, nie tylko diabła, który jest bezpośrednim wykonawcą woli Bożej, lecz samego Boga jako pierwszą przyczynę tych utrapień. Wniosek św. Augustyna wydaje się być zupełnie logicznym: skoro Bóg udziela diabłu pozwolenia na wyrządzenie szkody, to On też musi być za nią ostatecznie odpowiedzialny.

Za słusznością tego stanowiska świadczy również postawa samego Hioba, który będąc obciążonym licznymi cierpieniami, chociaż nie widzi sprawcy swego nieszczęścia, to jednak ,rozumie potęgę Boga” (potestatem Dei intellegere). Wie bowiem, że diabeł nie mógłby mu niczego zrobić bez pozwolenia Boga, do którego należy najwyższa władza ${ }^{45}$. Dlatego też nie zwraca on uwagi na wykonawcę, lecz kieruje ją ku Temu, kto zezwala, a sprowadzającą na niego wszelkie nieszczęścia działalność złego ducha nazywa działaniem „ręki Pańskiej" (manus Domini) ${ }^{46}$.

Obciążenie Boga odpowiedzialnością za zło, którego doświadcza Hiob, nie wyjaśnia jednak takiego postępowania Stwórcy, a wręcz wydaje się

15/2, Warszawa 1977, 446-447; tenże, Enarrationes in Ps. 21 (2), 4-5, NBA 25, 288-290, PSP 37 , 168-169; tamże 85, 9, NBA 26, 1258, PSP 40, 95-96.

${ }^{43}$ Por. tenże, Sermo 12, 8, CCL 41, 170; tenże, Enarrationes in Ps. 55, 20, NBA 26, 158, PSP 38, 363; tenże, Adnotationes in Job 1, NBA 10/3, 42.

${ }^{44}$ Tenże, Enarrationes in Ps. 31 (2), 26, NBA 25, 550: „Cuicumque aliquid accidit, dicat: Dominus dedit, Dominus abstulit. Ecce rectum cor: Sicut Domino placuit, ita factum est: sit nomen Domini benedictum. Quis abstulit? quid abstulit? cui abstulit? quando abstulit? Sit nomen Domini benedictum. Et non dixit, Dominus dedit, diabolus abstulit. Intendat ergo Caritas vestra, ne forte dicatis: Haec mihi diabolus fecit. Prorsus ad Deum tuum refer flagellum tuum, quia nec diabolus tibi aliquid facit, nisi ille permittat qui desuper habet potestatem, aut ad poenam, aut ad disciplinam", PSP 37, 291. Por. tenże, Epistula 130, 14, 26, PL 33, 504-505; I. Bochet, Cuore, ADE, s. 524.

${ }^{45}$ Por. Augustinus, Enarrationes in Ps. 90 (1), 2, NBA 27, 132-134, PSP 40, 175.

${ }^{46}$ Por. tamże 29 (2), 7, NBA 25, 414, PSP 29, 7. 
prowokować do poszukiwania jego przyczyn i ukrytych celów, by w ten sposób usprawiedliwić Go w oczach doświadczających cierpienia ludzi ${ }^{47}$. Wydaje się zatem, że krótkie spojrzenie na stanowisko Hippończyka wyrażone $\mathrm{w}$ tej kwestii jest niezbędne dla szerszego wyjaśnienia zarówno istoty potestas nocendi udzielonej diabłu, jak i roli Hioba w tak zarysowanym dramacie. Pozwoli to bowiem następnie dowiedzieć się na co i do jakiego stopnia tak naprawdę wyraża swą zgodę Bóg, kiedy pozwala diabłu dotknąć Hioba cierpieniem, czyli - innymi słowy - umożliwi określenie granic zakreślających pole, w którym może działać diabelska chęć szkodzenia.

\section{Potestas nocendi w planach Bożej Opatrzności - wystawienie na} próbę. Księga biblijna podaje, że diabeł, uzyskawszy pozwolenie, czyli władzę szkodzenia, realizuje ją przez wyrządzenie Hiobowi szkody dotyczącej rzeczy materialnych, utratę najbliższych oraz zadanie mu bólu cielesnego. Św. Augustyn widzi jednak istotę owego działania złego ducha w pokusie odwrócenia się od Boga, z którą zmaga się Hiob w kontekście spadających na niego cierpień i nieszczęśćc ${ }^{48}$. Tego też dotyczy więc w gruncie rzeczy pozwolenie Boga. Dlatego też biskup Hippony postępowanie Boga określa mianem doświadczania (potestas probandi) Hioba ${ }^{49}$.

Doświadczanie Hioba wydaje się być w pierwszym rzędzie odpowiedzią Bożą na oskarżające podejrzenie wysunięte przez złego ducha, a w konsekwencji formą zgody na jego niszczącą działalność. Jednak w nauczaniu biskupa Hippony można odkryć głębszy sens, który dostrzega on w pozwoleniu, jakiego Stwórca udziela diabłu. Określenie nieszczęść, jakie spadają na Hioba, mianem „doświadczania”, każe bowiem skierować uwagę nie tyle na taktykę demoniczna, ile na wewnętrzne racje wydanego pozwolenia, którego głównym adresatem jest nie diabeł, lecz Hiob. Nie chodzi tu zatem w gruncie rzeczy o wysłuchanie prośby diabła i zgodę na zło, lecz o odkrycie planów Bożych względem Hioba, które św. Augustyn nazywa „tajemniczą opieką Bożej Opatrzności" (occulta dispensatione providentiae Dei) ${ }^{50}$.

${ }^{47}$ Por. Mura, Introduzione, s. 34.

${ }^{48}$ Por. Augustinus, Adnotationes in Job 38, NBA 10/3, 154; tenże, Enarrationes in Ps. 103 (4), 8, NBA 27, 762-764, PSP 41, 64-65; G. Bolis, L'idolatria in S. Agostino. Una prospettiva antropologica, Roma 2004, 233-245.

49 Por. Augustinus, Enarrationes in Ps. 29 (2), 7, NBA 25, 414, PSP 27, 225; tense, Epistula 205, 2, 16, PL 33, 947-948; tenże, Sermo 15, 7, CCL 41, 198; tamże 57, 9, 9, PL 38, 390-391; tenże, De sermone Domini in monte II 9, 31-33, PL 34, 1282-1294. Św. Augustyn zauważa (Sermo 2, 3, CCL 41, 12) w związku z tym, że diabeł kusi, aby wprowadzić w błąd (decipere), zaś Bóg w celu pouczenia (docere). Ideę doświadczania Hioba przez Boga dobrze oddaje użyty przez św. Augustyna łaciński termin probo, -are, -avi, -atum oznaczający: „wystawiać na próbę, badać, oceniać, poddawać przeglądowi, uznawać, oceniać dodatnio, pochwalać, wykazać coś, dowieść, uzasadnić, okazać się, uchodzić za coś” (Plezia IV 299-300).

${ }^{50}$ Por. Augustinus, Enarrationes in Ps. 29 (2), 6, NBA 25, 412, PSP 37, 224. 
Hippończyk, śledząc plany Bożej Opatrzności w wydarzeniach opisanych na kartach Biblii oraz zaczerpniętych z historii Kościoła, zauważa, że Bóg udziela demonom władzy szkodzenia w trzech celach: dla ukarania grzeszników (np. gdy zezwala, by naród żydowski popadł w niewolę obcokrajowców ze względu na grzechy, jakich się dopuszczał), albo dla wypróbowania (co ma miejsce w przypadku Hioba), albo też dla chwały (np. gdy pozwala na śmierć męczenników) ${ }^{51}$. Dlatego też św. Augustyn podkreśla, że doświadczanie jest z jednej strony świadectwem udzielonym Hiobowi przez Boga, który zna jego serce $\mathrm{i}$ widzi jego bezinteresowną służbę ${ }^{52}$, zaś $\mathrm{z}$ drugiej strony jest formą ofiarowania mu Bożego dziedzictwa, gdyż - jak podkreśla biskup Hippony powołując się na Pismo Święte (Hbr 12,6) - Stwórca chłoszcze każdego, kogo przyjmuje za syna ${ }^{53}$.

Wydaje się, że w nauczaniu biskupa Hippony te dwa wymiary doświadczania Hioba są w pewnym stopniu powiązane ze sobą, a wzajemnie się warunkując, tworzą strukturę tego zjawiska, które Hippończyk określa mianem próby $^{54}$. Ukazanie sprawiedliwości Hioba dokonuje się bowiem na drodze otrzymanej od Boga chłosty w postaci dotykających go nieszczęść i cierpień, a one z kolei są formą Bożej pedagogiki, poprzez którą wychowuje On swe dzieci. Św. Augustyn ukazuje jej istotę następującymi słowami:

„chrześcijanin poddany cierpieniu jest doświadczany, czy nie opuścił swego Boga. Kiedy bowiem człowiekowi jest dobrze, chrześcijanin zdradza siebie. Ogień jest $\mathrm{w}$ piecu, a piec złotnika to wielka tajemnica. Zamknięty w nim ogień, włóż tam złoto i włóż plewy. Ogień jest ten sam, a odmienne skutki sprawia: plewy obraca w popiół, złoto oczyszcza z naleciałości. Ci, w których mieszka Bóg, rzecz jasna dzięki utrapieniom stają się lepsi, niby złoto oczyszczone. A gdyby (kogoś z nich) chciał nieprzyjaciel diabeł doświadczyć i otrzymałby na to zezwolenie, bądź przez zadanie mu jakiegoś bólu cielesnego, bądź przez wyrządzenie mu jakiejś szkody, bądź przez utratę najbliższych - niechaj serce jego będzie w tym, który sam tego nie uniknął. A jeśli się zdaje, że zamknął uszy na płacz, to jednak proszącemu udziela miłosierdzia. Ten, który nas stworzył wie, co ma czynić, umie też wzmocnić nas. Dobry to budowniczy, który potrafi dom zbudować, a jeśli coś w nim się uszkodzi, potrafi to naprawić" 55 .

${ }^{51}$ Por. tamże; tenże Sermo 9, 4, 4, PL 38, 569; tenże, Enarrationes in Ps. 31 (2), 26, NBA 25, 550, PSP 37, 291; tamże 77, 28, NBA 26, 1044, PSP 39, 395-396; tenże, Adnotationes in Job 16, NBA 10/3, 82; tenże, Epistula 205, 2, 16, PL 33, 947-948.

${ }^{52}$ Por. tenże, Enarrationes in Ps. 55, 20, NBA 26, 158, PSP 38, 362-363.

${ }^{53}$ Por. tenże, Adnotationes in Job 38, NBA 10/3, 154; tenże, Enarrationes in Ps. 31 (2), 26, NBA 25, 550, PSP 27, 292.

${ }^{54}$ Por. tenże, In Iohannis evangelium tractatus 43, 6, CCL 36, PSP 15/1, 514-515; tenże, De Trinitate I 7, 12, ed A. Trapè, NBA 4, Roma 2003, 144, tłum. M. Stokowska: Św. Augustyn, O Trójcy Świętej, POK 25, Poznań - Warszawa - Lublin 1962, 159.

${ }_{55}$ Tenże, Enarrationes in Ps. 21 (2), 5, NBA 25, 290: „quia in tribulatione positus christianus 
W dotykającym człowieka cierpieniu dostrzega zatem św. Augustyn znak Bożej Opatrzności. Dlatego też widziane z tej perspektywy, jawi się ono nie jako przekleństwo, lecz jako środek doskonalenia, lekarstwo na chorobę grzechu, poprzez które Boski Lekarz uzdrawia ludzką duszę. Zezwolenie Boga na szkodzace działanie diabła nie ma zatem na celu zniszczenie człowieka, lecz jego poprawę i odzyskanie przez niego duchowego zdrowia ${ }^{56}$. Dlatego też Bóg, udzielając pozwolenia diabłu na szkodzenie Hiobowi, czyni podobnie jak lekarz, który musi wobec chorego zastosować środki sprawiające mu ból, a chociaż spotyka się z jego strony z niezrozumieniem, a nawet sprzeciwem, to jednak nie zaprzestaje tych czynności, bo ostatecznie służą one dobru pacjenta $^{57}$. Z tego względu takie postępowanie Boga nazywa biskup Hippony czynem i znakiem miłosierdzia, które wyraża się zarówno w tym, czego On udziela, jak i w tym, co zabiera ${ }^{58}$.

Patrząc zatem z tej perspektywy, jasnym staje się ukazany wyżej paradoks polegający na tym, że Bóg wysłuchuje prośby diabła, pozwalając mu szkodzić Hiobowi, zaś nie spełnia wołania Apostoła, błagającego o oddalenie zesłanych na niego utrapień. Św. Augustyn zauważa bowiem, że św. Paweł nie otrzymuje spełnienia próśb ze względu na swe udoskonalenie i - w ostateczności - zbawienie, zaś diabeł zostaje wysłuchany na własne potępienie (ad damnationem suam) ${ }^{59}$.

probatur, si non dereliquit Deum suum. Nam quando bene est homini, desertus est sibi christianus. Ignis intrat in fornacem, et fornax aurificis magni sacramenti res est. Ibi est aurum, ibi est palea, ibi ignis in angusto operatur. Ignis ille non est diversus, et diversa agit; paleam in cinerem vertit, auro sordes tollit. In quibus autem habitat Deus, utique in tribulatione meliores fiunt, tamquam aurum probati. Et si forte petierit inimicus diabolus, et concessum illi fuerit: sive aliquo dolore corporis, sive aliquo damno, sive amissione suorum, fixum cor habeat in illo qui se non subtrahit; et si quasi subtrahit aurem ploranti, sed apponit misericordiam deprecanti. Novit quid agat qui nos fecit, novit et reficere nos. Bonus est structor qui aedificavit domum; et si aliquid ibi ceciderit, novit resarcire", PSP 37, 169. Zob. tenże, De civitate Dei XIX 13, CCL 48, 679-680, thum. Kubicki, s. 780-781; tenże, Adnotationes in Job 38, NBA 10/3, 154; Kowalczyk, Człowiek i Bóg w nauce św. Augustyna, s. 147.

${ }^{56}$ Por. Augustinus, Sermo 12, 2, CCL 41, 165-166; tenże, Enarrationes in Ps. 85, 9, NBA 26, 1258, PSP 40, 96; S. Jaśkiewicz, Św. Augustyn - poszukiwanie Boga, Katowice 2012, 139; Bolis, L'idolatria in S. Agostino, s. 246-251.

${ }^{57}$ Por. Augustinus, Enarrationes in Ps. 144, 22, ed. V. Tarulli, NBA 28, Roma 1977, 720-722, PSP 42, 300.

${ }^{58}$ Por. tamże 144, 4, NBA 28, 690, PSP 42, 285; Jaśkiewicz, Św. Augustyn - poszukiwanie Boga, s. 140. Dlatego też F. van Fleteren (Diavolo, ADE, s. 555) pisze: „Dio può tuttavia usare a buon fine la malizia del diavolo".

${ }^{59}$ Por. Augustinus, Adnotationes in Job 1, NBA 10/3, 42; tamże 144, 19, NBA 28, 716-718, PSP 298. Św. Augustyn (tamże) zauważa przy tym, że jakkolwiek Apostoł Paweł nie został wysłuchany, to jednak prośbę Hioba Bóg spełnił, choć po dłuższym czasie pozostawiania go w cierpieniach. Jest to dla biskupa Hippony wskazówka i zachęta do tego, by nigdy nie ustawać w modlitwie i prosić Boga z ufnością w Jego miłosierdzie nawet wówczas, gdy wydaje się, że modlitwa nie została wysłuchana. Tym bardziej wówczas chrześcijanin zobowiązany jest do ufnej modlitwy i błogosławienia Boga nawet w cierpieniu. Rzeczą najważniejszą jest bowiem zbawienie człowieka, a nie jego wygodne życie na ziemi. Dlatego też postępowanie Boga zsyłającego na ludzi rozmaite utrapienia należy więc oceniać z perspektywy celu, do którego ono zmierza. Taka postawa jest ważna również z innego jeszcze 
Można zatem zauważyć, że skoro zgoda na zło, które miało spaść na Hioba, jest rodzajem próby mającej na celu ukazanie oraz oczyszczenie jego sprawiedliwości, to wobec tego udzielenie przez Boga mocy działania dla diabelskiej chęci szkodzenia, nie oznacza wcale przyznania racji wysuwanemu przez złego ducha oskarżeniu, lecz wręcz służy wykazaniu, że jest ono fałszywe i pozbawione podstaw. Bóg, udzielając więc diabłu potestas nocendi, nie popiera jego podejrzewającego oskarżenia, lecz wprost przeciwnie - opowiada się za Hiobem, stając się nawet jego obrońcą ${ }^{60}$. Dlatego też św. Augustyn w swej interpretacji dziejów Hioba stwierdza, że dopuszczenie nieszczęść, jakie na niego spadły, nie oznacza opuszczenia go przez Boga. Podkreśla bowiem, że Hiob, nawet $\mathrm{w}$ trudnej sytuacji choroby i cierpienia, pozostaje ,ukryty w skrytości oblicza Boga" (in abscondito vultus Dei), który jest obecny w jego sercu, będąc jego wewnętrznym pasterzem (interior pastor) i pocieszycielem (consolator) W znoszonych z cierpliwością utrapieniach ${ }^{61}$. W takim wypadku doświadczanie Hioba nie świadczy ani o niesprawiedliwości Boga, ani tym bardziej o wielkości władzy udzielonej diabłu. Wręcz przeciwnie, gdyż - jak ilustruje to św. Augustyn - Stwórca z duszy sprawiedliwego Hioba czyni włócznię (framea), która staje się w Jego ręku narzędziem przezwyciężenia działań złego ducha ${ }^{62}$.

Patrząc na zagadnienie potestas nocendi z tak zarysowanej perspektywy, można zauważyć, że chociaż przy pobieżnej lekturze analizowanej księgi biblijnej, diabeł wydaje się posiadać wielką władzę nad Hiobem, a Bóg postępuje tak, jakby sprzyjał zamysłom nieprzyjaciela rodzaju ludzkiego, to jednak interpretacja tych wydarzeń dokonana przez biskupa Hippony zupełnie odwraca ten pozorny porządek rzeczy. $\mathrm{W}$ istocie bowiem, czyli w planach Bożej Opatrzności, diabeł jest przegranym i to nie tylko w finale doświadczania Hioba, lecz już w początkach podjętej próby zniszczenia go, a udzielona mu władza obraca się przeciwko niemu. Dlatego też św. Augustyn, posługując się porównaniem do procesu wytwarzania trąb, nazywa złego ducha „młotem w ręku Boga" (malleus in manu Dei posito), dzięki któremu wykuwa On pięknie brzmiącą i głoszącą chwałę Bożą trąbę, czyli przyczynia się do uformowania i udoskonalenia duszy sprawiedliwego człowieka ${ }^{63}$. Paradoks tej sytuacji polega na tym, że diabeł, chcąc zniszczyć Hioba, staje się narzędziem jego uświęcenia, a rzucone na niego oskarżenie obraca się w usprawiedliwienie oskarżonego. Prowokując więc Boga, by móc wystąpić przeciwko Hiobowi,

powodu. Otóż Hippończyk wydaje się uznawać, że nawet gdy znane są te motywy działania Bożego i powody, dla których pozwala On na rozmaite doświadczenia ludzi, to jednak zamiary Stwórcy odnośnie do konkretnego człowieka, nie dają się do końca wyjaśnić. Pozostają one ciaggle dla ludzkiego umysłu ,głęboką tajemnicą (magnum mysterium)", z którą człowiek musi się zmierzyć pytając Boga w modlitwie. Zob. tenże, De Genesi ad litteram XI 4, 6, NBA 9/2, 564, PSP 25, 320-321.

${ }^{60}$ Por. tenże, De sermone Domini in monte II 9, 30, PL 34, 1282.

${ }^{61}$ Por. tenże, Enarrationes in Ps. 30 (4), 12, NBA 25, 504, PSP 37, 268.

${ }^{62}$ Por. tenże, Adnotationes in Job 16, NBA 10/3, 84; tenże, Enarrationes in Ps. 34 (1), 7, NBA 25, 678, PSP 37, 355; tenże, De diversis quaestionibus ad Simplicianum II 1, 4, PL 40, 131-132.

${ }^{63}$ Por. tenże, Enarrationes in Ps. 97, 6, NBA 27, 408-410, PSP 40, 300-301. 
przyczynia się do własnej klęski ${ }^{64}$. Tę tajemniczą i trudną do zrozumienia przemianę Hippończyk wyjaśnia następującymi słowami:

„Nikt z wiernych nie wątpi, że diabeł i aniołowie jego są źli, że przygotowany im jest ogień wieczny. Ale żeby Bóg przez nich nawiedzał kogokolwiek, zwłaszcza kogo uzna za godnego ukarania, wydaje się rzeczą trudną do zrozumienia, zwłaszcza dla tych, którzy nie są na tyle przygotowani pomyśleć, w jaki sposób najwyższa sprawiedliwość Boga może posłużyć się dla dobra, nawet złymi duchami. Otóż czy te złe duchy, gdy chodzi o ich substancję, stworzył ktoś inny niż Bóg? Złymi ich jednak nie uczynił. Posługuje się jednak nimi, ponieważ jest dobry, dobrze, czyli odpowiednio i sprawiedliwie się nimi posługuje, a przeciwnie, niegodziwi posługują się źle nawet jego dobrymi stworzeniami. Bóg zatem posługuje się złymi aniołami nie tylko dla karania złych [...]. Bóg posługuje się także złymi dla wypróbowania i ujawnienia dobrych, jak to miało miejsce z Jobem"65.

Z perspektywy Boga zatem, zarówno sytuacja rozgrywająca się na pierwszej, jak i na drugiej scenie opisywanego w biblijne księdze dramatu wydaje się być jasna i zmierzająca do dobrego celu. Niemniej jednak należy pamiętać i o tym, że skoro doświadczanie Hioba przez Boga za pomocą diabła jako narzędzia, jest próbą, to zakłada ono również jakąś odpowiedź ze strony tego, kto jej zostaje poddany, a to oznacza, że jej wynik nie dla wszystkich uczestników tej historii jest oczywisty. Chociaż św. Augustyn w tak pewny sposób pisze o próbie, jakiej zostaje poddany Hiob i o jego zwycięstwie, to jednak, wydaje się, że w jego analizach pobrzmiewa również nutka dopuszczająca jakieś ryzyko. Próba nie zawsze przecież musi się powieść. Pole rozmaitych możliwości otwiera bowiem ludzka wolna wola, która sprawia, że próba jest właśnie próbowaniem i oczekiwaniem na niepewny wynik. Tego rodzaju spojrzenie ukazujące ryzyko, jakie ponosi Bóg wystawiając człowieka na próbę, biskup Hippony ukazuje jednak przede wszystkim z perspektywy doświadczanego człowieka oraz szkodzącego mu diabła. Próba, której poddany jest Hiob, odsyła zatem do ponownego spojrzenia na jego cierpienia, lecz już z perspektywy

${ }^{64}$ Por. tenże, Adnotationes in Job 1, NBA 10/3, 42; tenże, Enarrationes in Ps. tamże 97, 6, NBA 27, 408-410, PSP 40, 300-301; tenże, De civitate Dei XVI 32, CCL 48, 336-337, tłum. Kubicki, s. 421; tenże, De Genesi ad litteram XII 17, 34, NBA 9/2, 674, PSP 25, 362-363; tenże, De diversis quaestionibus ad Simplicianum II 1, 4, PL 40, 131-132; tenże, Sermo 354, 7, 7, PL 39, 1566.

${ }^{65}$ Tenże, Enarrationes in Ps. 77, 28, NBA 26, 1044: „Esse autem diabolum et angelos eius tam malos utique, ut eis ignis praeparetur aeternus, nullus fidelis ignorat: sed immitti per eos immissionem super quoslibet a Domino Deo, quos hac poena iudicat dignos, durum videtur eis qui minus idonei sunt cogitare quemadmodum summa Dei iustitia bene utatur et malis. Quos quidem, quantum pertinet ad eorum substantiam, quis alius quam ipse fecit? Sed malos ipse non fecit: utitur tamen eis, quoniam bonus est, bene, id est convenienter et iuste; sicut e contra iniqui creaturis eius bonis utuntur male. Utitur ergo Deus angelis malis, non solum ad puniendos malos, [...] verum etiam ad probandos et manifestandos bonos, sicuti fecit in Iob", PSP 39, 395. Zob. Epistula 205, 2, 16, PL 33, 947-948; F. van Fleteren, Demoni, ADE, s. 539-541. 
dotychczasowych analiz dotyczących drugiej sceny dramatu. W ich świetle można bowiem jaśniej ujać to, co przydarza się Hiobowi, czyli to, na czym $\mathrm{w}$ istocie polega diabelska moc szkodzenia i ku czemu ona zmierza, a z kolei postawa Hioba pozwala obecnie na wyraźniejsze określenie rzeczywistości duchowej koncentrującej się wokół omawianego wyżej dialogu diabła z Bogiem.

4. Potestas nocendi jako kuszenie. Oskarżenie wysuwane przez diabła wobec Hioba podejrzewa go o interesowną służbę Bogu, czyli - jak określono to wyżej - tak naprawdę o pewnego rodzaju nieszczerość i fałszywą pobożność. Interesowność lub bezinteresowność zaś, opisując z jednej strony relację Hioba do Boga, zaś z drugiej sposób posiadania rzeczy doczesnych, odsyłają do wewnętrznej struktury ludzkiej natury ukonstytuowanej przez rozum i wolę, a którą biskup Hippony określa mianem serca $(c o r)^{66}$. Chociaż bowiem - jak podkreśla Hippończyk - diabeł nie ma dostępu do ludzkiego serca, a jego oddziaływanie wola Boga zostaje ograniczone tylko do tego, co Hiob posiada oraz do jego ciała ${ }^{67}$, to przecież wyłącznie jego serce jest polem, na którym może być określone jego odniesienie do Boga i świata w wymiarze doczesnym i materialnym. Wobec tego to właśnie ono staje się głównym „przedmiotem” oddziaływania diabelskiej władzy szkodzenia.

Oznacza to, że próba, jakiej zostaje poddany Hiob, odwołując się do jego wolności, musi wymagać odpowiedzi, czyli wyboru, ponieważ tylko w ten sposób może odsłonić się prawdziwość lub fałsz oskarżycielskiego podejrzenia wysuwanego przez złego ducha. Skoro zatem dopiero wybór, przed jakim zostaje postawiony Hiob, objawia prawdę o jego relacji do Boga i świata, a nie czyni tego sama zgoda na szkodzenie, ani tym bardziej nieszczęścia, jakich doświadcza główny bohater, to znaczy, że owa próba jest w swojej istocie kuszeniem (tentatio, suggestio) ${ }^{68}$. Tylko tego rodzaju działanie złego ducha może dotykać ludzkiego serca, będąc jakimś sposobem nakłaniania jego woli

${ }^{66}$ Por. Augustinus, Enarrationes in Ps. 103 (4), 7, NBA 27, 760, PSP 40, 63; T. Špidlik - I. Gargano - V. Grossi, Historia duchowości, t. 3: Duchowość Ojców Kościoła, thum. K. Stopa, Kraków 2004, 362-363; Kowalczyk, Człowiek i Bóg w nauce św. Augustyna, s. 149-150; D. Pagliacci, Male e peccato: „De civitate Dei” XVI. Riflessi antropologici, w: Il mistero del male e la libertá possibile (III): Lettuta del „De civitate Dei” di Agostino, ed. L. Alici - R. Piccolomini - A. Pieretti, Roma 1996 = SEA 54 (1996) 199; Bolis, L'idolatria in S. Agostino, s. 242-243; Bochet, Cuore, ADE, s. 524.

${ }^{67}$ Por. Augustinus, Adnotationes in Job 1, NBA 10/3, 42; tamże 38, NBA 10/3, 154; tenże, Enarrationes in Ps. 103 (4), 7, NBA 27, 760, PSP 40, 63.

${ }^{68}$ Por. tenże, Sermo 12, 9, CCL 41, 171; tenże, Enarrationes in Ps. 100, 12, NBA 27, 502, PSP 40, 344; tenże, Epistula 130, 14, 26, PL 33, 504-505; tenże, De diversis quaestionibus ad Simplicianum II 3, 1, PL 40, 142; tenże, Epistula 205, 2, 16, PL 33, 947-948. Zrozumienie istoty owego kuszenia jest możliwe w szerszym zakresie w kontekście uwzględniających augustyńską koncepcję wartości i ich hierarchii. Zob. Kowalczyk, Człowiek i Bóg w nauce św. Augustyna, s. 136-137; M.F. di Silva, Agostino e il problema del negativo pluralità e unità delll'identità di male e nulla, w: I conflitti religiosi nella scena pubblica, t. 1: Agostino a confronto con manichei e donatisti, ed. L. Alici, Roma 2015, 105-110. 
do dokonania konkretnego, zamierzonego wyboru. Zgoda Boga na szkodzenie Hiobowi jest zatem nie tyle pozwoleniem na zniszczenie go, ile na kuszenie go ${ }^{69}$. Próba rozumiana jako kuszenie dobrze opisuje również istotę tego, z czym musi zmagać się Hiob poddany diabelskiej władzy szkodzenia.

Św. Augustyn, opisując sytuację, w której znajduje się doświadczany przez diabła Hiob, porównuje ją do kuszenia Adama w rajskim ogrodzie, a dostrzegając pomiędzy tymi postaciami pewną analogię, rozwija również paralelę pomiędzy żoną Hioba a żoną Adama, Ewą. Zachodzące między nimi podobieństwo wyjaśnia bowiem wiele z istoty diabelskiego kuszenia, które Hippończyk opisuje w następujących słowach:

„Ów święty Job siedział na kupie gnoju, a biegł drogą. [...] on odpędzał kuszącego, tamten spodziewał się, że będzie miał upadłego. Pochwycił i jego kobietę; odebrał wszystko, co posiadał, zostawił jedynie swoją wspomożycielkę, nie pocieszycielkę męża, ale raczej kusicielkę. [...] Ona bowiem też była Ewa, ale on już nie był Adamem. Utraciwszy wszystko Job pozostał z żoną, która go kusiła i z Bogiem, który nim rządził. [...] Uzyskał zezwolenie w stosunku do jego ciała, od stóp do głowy pokrył je straszliwymi wrzodami, powoli obejmowała go zgnilizna, toczyło robactwo, wyrzucony z domu siedział na gnoju. W tym stanie Ewa już schwytana przez diabła, a nie przydana mężowi na pomoc, lecz ku upadkowi, namawiała, żeby bluźnił Bogu. Najpierw namawiała w raju, żeby zlekceważyć Boga, teraz, żeby Mu bluźnić"’70.

Można zauważyć, że owa pokusa diabelska, podsuwana Hiobowi przez jego żonę, posiada szczególnie subtelny charakter. Opiera się ona bowiem na obarczeniu Boga odpowiedzialnością za doznane nieszczęścia i choroby. Jednak w podobny sposób myśli przecież i sam Hiob, gdy - jak zostało to wyżej wspomniane - w dotykających go cierpieniach dostrzega przede wszystkim rękę Boga, a nie tylko działanie diabła. Diagnoza sytuacji jest zatem w obu przypadkach taka sama, różnią się one jednak wyciągniętym z nich wnioskiem. Żona zachęca bowiem Hioba do bluźnierstwa Bogu, czyli do przypisania $\mathrm{Mu}$

${ }^{69}$ Por. Augustinus, Sermo 12, 9, CCL 41, 171; tenże, Enarrationes in Ps. 103 (4), 7, NBA 27, 760, PSP 40, 63.

${ }^{70}$ Tenże, Enarrationes in Ps 103 (4), 7, NBA 27, 760: „Iob ille sanctus sedebat in stercore, et currebat in via [...]. Ille repellebat suggerentem, ille sperabat labentem: cepit et eius mulierculam; subtraxit omnia quae habebat, solam dimisit adiutricem suam, non mariti consolatricem, sed potius tentatricem; [...] Adhuc enim illa Eva erat; sed iam ille Adam non erat. Ablatis omnibus, remansit Iob cum uxore, per quam tentaretur; et cum Deo, a quo regeretur. [...]Accessit alia tentatio: permissus est ad corpus eius, percussit gravi vulnere a capite usque ad pedes; contabescebat putredine, scatebat vermibus, amissa domo sedebat in stercore. Ibi Eva captivata, a diabolo non ad adiutorium marito supposita, sed ad lapsum, suggerit ut blasphemetur Deus. Primo suggessit in paradiso ut contemneretur Deus, modo ut blasphemetur Deus", PSP 41, 63. Zob. tenże, De patientia 12 9, PL 40, 616; tenże, Sermo 81, 2, PL 38, 500; tamże 22A, 4, CCL 41, 305; tamże 343, 10, PL 39, 1511; tenże, Contra Gaudentium I 30, 35, ed. E. Cavallari, NBA 16/2, Roma 2000, 484-486; tenże, Contra Cresconium III 48, 52, PL 43, 525; Fleteren, Diavolo, ADE, s. 555. 
niesprawiedliwości i buntu przeciwko Niemu ${ }^{71}$, zaś Hiob, w przeciwieństwie do biblijnego Adama, odpowiada błogosławieństwem Pana ${ }^{72}$. Istotę pokusy podsuwanej przez ową kusicielkę odczytuje bowiem biskup Hippony następująco:

„Niewidzialni nieprzyjaciele szczególnie walczą przeciwko nam. Sugerują sercom ludzkim, że Bóg nie jest naszym wspomożeniem. Chodzi im o to, abyśmy poszukując innej pomocy, okazali się bezbronni, abyśmy zostali pojmani przez tychże samych nieprzyjaciól"’3 .

Dla św. Augustyna pokusa, którą podsuwa złych duch posługując się żoną Hioba, pozostaje także ściśle związana z cierpieniami i stratą majątku oraz rodziny. Posiada ona zatem podwójny charakter, choć tworzące ją kierunki pozostają przecież współzależne od siebie. Słowa kusicielki wydają się bowiem być konsekwencją i szczytowym punktem tego, co diabeł z przyzwolenia Bożego czyni w stosunku do Hioba. Wobec tego proponowane bluźnierstwo byłoby nie tylko buntem przeciwko Bogu, lecz także odsłaniałoby niewłaściwą relację Hioba do swego majątku i rodziny, przez co potwierdzałoby oskarżenie złego ducha podejrzewającego go o interesowną pobożność. Służba Bogu ze względu na otrzymane od Niego dobra świadczy bowiem nie o pobożności, lecz o przywiązaniu do rzeczy doczesnych. Dla biskupa Hippony oznacza to tyle, co odniesienie czci Boga do dóbr, jakich On udziela oraz związanie się $\mathrm{z}$ nimi $\mathrm{w}$ takim stopniu, że posiadanie ich staje się celem samym $\mathrm{w}$ sobie. Wówczas człowiek, pod pozorem zewnętrznych czynów pobożnych, tak naprawdę służy rzeczom cielesnym, które są dla niego źródłem pociechy (consolatio). To jednak jest równoznaczne $\mathrm{z}$ utratą $\mathrm{Boga}^{74}$. Celem pokusy diabelskiej i związanej z nią władzy szkodzenia jest więc wzbudzenie lub odkrycie w Hiobie pożądliwości ukazującej, że bardziej kocha on to, co posiada niż samego Boga $^{75}$.

${ }^{71}$ Por. Augustinus, De patientia 12 9, PL 40, 616; tenże, Sermo 81, 2, PL 38, 500; tenże, Enarrationes in Ps. 70 (1), 14, NBA 26, 740, PSP 39, 246; tenże, Contra Cresconium III 48, 52, PL 43, 525; A. Eckmann, Przebóstwienie człowieka w pismach wczesnochrześcijańskich, Lublin 2003, 145-147.

72 Por. Augustinus, Sermo 22 A, 4-5, CCL 41, 305-306; tamże 343, 10, PL 39, 1511; tenże, Adnotationes in Job 23, NBA 10/3, 98-100.

73 Tenże, Enarrationes in Ps. 34 (1), 5, NBA 25, 674: „Maxime suggeritur humano cordi ab invisibiliter expugnantibus inimicis, quia Deus nobis non est adiutor: ut requirentes alia adiutoria, inveniamur invalidi, et ab inimicis ipsis capiamur”, PSP 37, 352. Św. Augustyn, przez zastosowany tutaj termin: suggero, -ere, -gessi, -gestum rozumany jako: „podkładać coś pod coś, podsunąć, dostarczać, przynosić, przypominać o czymś, budzić pragnienie czegoś, doradzać" (Plezia V 282) wskazuje na związek pomiędzy kuszeniem a oskarżającym podejrzeniem, jakie diabłeł wysuwa pod adresem Hioba.

${ }^{74}$ Por. Augustinus, De civitate Dei XIX 13, CCL 48, 679-680, tłum. Kubicki, s. 780-781; tenże, Enarrationes in Ps. 36 (2), 10, NBA 25, 778-790, PSP 38, 10; D. Zagórski, Commendavit nobis Dominus oves suas. Pasterska troska o wiernych w świetle ,, Sermones ” św. Augustyna, Toruń - Pelplin 2013, 389-391; Kowalczyk, Człowiek i Bóg w nauce św. Augustyna, s. 147.

75 Por. Augustinus, Enarrationes in Ps. 103 (4), 9, NBA 27, 760-762, PSP 41, 65; tamże 47, 9, 
Św. Augustyn zauważa przy tym, że związek pomiędzy ukazanymi kierunkami działania diabelskiej pokusy, czyli buntem przeciw Bogu i przywiązaniem do rzeczy cielesnych, jest możliwy wyłącznie z tego powodu, że mają one wspólne źródło i stanowią jedną alternatywę dla wyboru, jakiego musi dokonać kuszony Hiob. Owym źródłem jest zaś ludzka wolna wola. Wszystkie nieszczęścia i choroby, jakie dotykają Hioba, wymagają bowiem od niego ustosunkowania się do nich - przyjęcia ich lub odrzucenia. Ten podstawowy wybór umożliwia zatem dopiero bunt wobec Boga, przywiązanie do spraw doczesnych oraz interesowność lub bezinteresowność hiobowej pobożności. W jego świetle wyraźniejsze i bardziej widoczne staje się również Boże pozwolenie na diabelską chęć szkodzenia oraz sama istota potestas nocendi, która tutaj właśnie znajduje swój główny cel. Biskup Hippony, nawiązując do modlitwy Jezusa w Ogrodzie Oliwnym, naucza o tym wyborze i stojących przed Hiobem możliwościach w następujących słowach:

„Popatrz jednak jak ich wiedzie ku prawości serca. Oto ty chciałeś żyć, nie chciałeś, aby ci się coś przytrafiło, ale Bóg chciał czegoś innego. Oto dwie wole, ale twoja wola dostosowała się do woli Bożej, a nie wola Boża nakłoniła się do twojej. Twoja wola jest skłonna do zła, prawidłem jest wola Boga. Prawidło się nie zmienia, a to, co jest skłonne do zła, dopasowuje się do prawidła. Zobaczcie, jak o tym naucza Pan Jezus Chrystus: «Smutna jest moja dusza aż do śmierci; Ojcze, jeśli można, niechaj odejdzie ode mnie ten kielich». Oto ukazał ludzką wolę. Dostrzeż też i prawe serce: «Ale nie jako ja chcę, ale jako Ty chcesz, Ojcze» (Mt 26, 38-39). Tak zatem postępuj radując się z tego, co cię spotyka""

W wystawiającej na próbę pokusie chodzi więc o skłonienie Hioba, by jego ludzka wola, wzbraniająca się przed cierpieniem i kierująca się ku zmiennym rzeczom cielesnym, wzięła górę nad przyjęciem woli Bożej ${ }^{77}$. W tym za-

NBA 25, 1182, PSP 38, 214; Mura, Introduzione, s. 33; Jaśkiewicz, Św. Augustyn - poszukiwanie Boga, s. 140; Zagórski, Commendavit nobis Dominus oves suas, s. 393-394.

${ }^{76}$ Augustinus, Enarrationes in Ps. 31 (2), 26, NBA 25, 550: „Sed vide quomodo eos ducit in directionem cordis. Ecce tu volebas vivere, non volebas tibi aliquid accidere; sed Deus aliud voluit: duae voluntates sunt; sed voluntas tua corrigatur ad voluntatem Dei, non voluntas Dei detorqueatur ad tuam. Prava est enim tua, regula est illa: stet regula, ut quod pravum est, ad regulam corrigatur. Videte quomodo hoc docet Dominus Iesus Christus: Tristis est anima mea usque ad mortem: et: Pater, si fieri potest, transeat a me calix iste. Ecce ostendit humanam voluntatem. Sed vide rectum cor: Verum non quod ego volo, sed quod tu vis, Pater. Hoc ergo fac, gaudens in his quae tibi accidunt", PSP 37, 292. Więcej o koncepcji wolnej woli u św. Augustyna zob. M. Djuth, Volontà, ADE, s. 1460-1466.

${ }^{77}$ Por. Augustinus, De civitate Dei I 10, CCL 47, 10-11, thum. Kubicki, s. 32-33; tenże, De Genesi ad litteram 11, 4, 6, NBA 9/2, 564, PSP 25, 320-321; Zagórski, Commendavit nobis Dominus oves suas, s. 388-391; A. Eckmann, Symbol apostolski w pismach świętego Augustyna, Lublin 1999, 152-153; N. Cipriani, Molti e uno solo in Cristo. La spiritualità di Agostino, Roma 2009, 352-356; Djuth, Volontà, ADE, s. 1464-1466; A. Pieretti, Agostino e l'origine del male, w: I conflitti religiosi nella scena pubblica, t. 1, s. 77-78. Św. Augustyn zauważa zatem (Enarrationes in Ps. 76, 2, NBA 26, 970, PSP 39, 357; tamże 93, 19, NBA 27, 278-282, PSP 40, 242-244; tamże 144, 22, NBA 28, 
tem wyraża się najgłębsza istota owego buntu, ku któremu nakłania Hioba jego żona oraz wszelkich działań, jakie podejmuje względem niego diabelska chęć szkodzenia. W kuszeniu chodzi więc o ty, by nakłonić wolę Hioba do zwrócenia się ku światu, i jednocześnie odwrócenia się od Boga ${ }^{78}$.

Przytoczone słowa św. Augustyna wyraźniej odsłaniają istotę potestas nocendi widzianej także z perspektywy Bożej Opatrzności. Okazuje się bowiem, że Hiob dzięki wsparciu Boga i Jego mocą (potestas Dei) ${ }^{79}$, rozpoznając w swym cierpieniu rękę swego Pana, błogosławi Mu i z ufnością przyjmuje Jego wolę. Jego postawa wyrażona w słowach: „Pan dał i zabrał Pan. Niech będzie imię Pańskie błogosławione. [...] Dobro przyjęliśmy z ręki Boga, czemu zła przyjąć nie możemy?" (Hi 1, 21;2, 10), jest dla św. Augustyna świadectwem złączenia ludzkiej woli cierpiącego człowieka z wolą Boga oraz dobrowolną ofiarą (sacrificatio) złożoną Bogu z samego siebie ${ }^{80}$. Ofiara ta wyklucza zaś wszelką interesowność zadając kłam podejrzliwemu oskarżeniu diabła.

W niej również stają się lepiej widoczne powiązane ze sobą dwie przyczyny udzielenia złemu duchowi przez Boską Opatrzność mocy szkodzenia, a mianowicie: omówione już wyżej ujawnienie sprawiedliwości Hioba oraz udoskonalenie go. Hippończyk bowiem podkreśla, że niszczące działanie diabła i namowy jego współpracownicy nie tylko nie dotykają serca Hioba, lecz właśnie odsłaniają jego wewnętrzne bogactwo (divitiae cordis) $)^{81}$. Hiob zatem - jak w bardzo obrazowy sposób objaśnia biskup Hippony - tracąc „chwałę pierwotnego blasku płynącego z rzeczy doczesnych (gloria pristinae lucis temporalium rerum)" "82, odkrywa tkwiącą w nim „wewnętrzną światłość

720, PSP 42, 299) w tym kontekście, że zwycięstwo ludzkiej woli w człowieku objawia się poprzez to, że wielu spośród ludzi woła do Pana prosząc Go o własne zdrowie, o doczesne szczęście, bogactwa lub godności, o uniknięcie wszelkich szkód i nieszczęść, wybawienie od nieprzyjaciół, słowem - proszą Go o wiele rzeczy, lecz nie proszą o Niego samego.

${ }^{78}$ Por. Bolis, L'idolatria in S. Agostino, s. 233-245; Terka, ,, Corpus diaboli”, s. 350-352.

${ }^{79}$ Por. Augustinus, Enarrationes in Ps. 97, 6, NBA 27, 408, PSP 40, 301.

${ }^{80}$ Por. tenże, Adnotationes in Job 1, NBA 10/3, 42; tenże, Enarrationes in Ps. 76, 2, NBA 26, 970, PSP 39, 358; N. Cipriani (Molti e uno solo in Cristo, s. 368-369) pisze: „Servendo Dio con amore in ogni circostanza, il cristiano tranforma la sua vita in un sacrificio a lui gradito, facendo così risplendere in sé la figura di Cristo servo, sacerdote è vittima. [...] Quando il corpo viene usato dall'anima per uno scopo buono e onesto in riferimento a Dio, è un sacrificio a Dio. A più forte ragione è sacrificio l'anima stessa, quando si offre a Dio, affinché, accesa dal fuoco del suo amore, si spogli dei desideri del mondo e, sottomessa a lui, modello immutabile, si rinnovi e si faccia bella della sua belezza, per piacergli”.

${ }^{81}$ Por. Augustinus, Enarrationes in Ps. 103 (4), 7, NBA 27, 760, PSP 41, 63; tamże 37, 24, NBA 25, 374, PSP 38, 56; tenże, De civitate Dei I 10, CCL 47, 10-11, tłum. Kubicki, s. 32-33; Fleteren, Diavolo, ADE, s. 555; Bochet, Cuore, ADE, s. 524-530; A. Pierini, Agostino e l'impegno nella lotta contro il male, w: I conflitti religiosi nella scena pubblica, t. 1, s. 102-103.

${ }^{82}$ Por. Augustinus, Enarrationes in Ps. 144, 18, NBA 28, 716, PSP 42, 297; tenże, Sermo 392, 3, PL 39, 1710-1711; H. Häring, Malum, w: Augustinus-Lexicon, hrsg. C. Mayer - A.E.J. Grotte, vol. 3, Basel 2004-2010, 1115. 
(lux interior in corde)" "83, której źródłem jest Pan zamieszkujący w jego ser$\mathrm{cu}^{84}$. Owo wewnętrzne bogactwo Hioba polega - zdaniem św. Augustyna - na posiadaniu czystego sumienia. Ono bowiem jest tym, co odsłania najtajniejszą istotę człowieka oraz miejscem spotkania z Bogiem i przyjmowania Jego światła ${ }^{85}$, dzięki któremu Hiob, choć pozbawiony wszystkiego i przygnieciony chorobami, jest ,piękny w oczach Bożych (pulcher coram oculis Dei)" ${ }^{\prime 6}$.

Pokusa diabelska i związana z nią utrata stanu posiadania oraz zdrowia, uwalniając niejako wewnętrzny blask sprawiedliwości Hioba, nie tylko czyni chybionym podejrzenie kusiciela, lecz także pozwala samemu cierpiącemu człowiekowi poznać własne oddanie Bogu, a poprzez to jeszcze bardziej umocnić się $\mathrm{w}$ woli bezinteresownego służenia $\mathrm{Mu}^{87}$. Paradoksalnie zatem, zewnętrzny upadek Hioba sprawia, że może on już bez żadnego przywiązania do rzeczy cielesnych (bo ich po prostu nie posiada) oraz dzięki dokonanemu wyborowi zgody z wolą Boga, postawić Go ponad wszelkimi innymi wartościami doczesnymi i duchowymi ${ }^{88}$, pokładając w Nim całą swoją ufność ${ }^{89}$. Na

${ }^{83}$ Por. Augustinus, Enarrationes in Ps. 144, 4, NBA 28, 690, PSP 42, 284.

${ }^{84}$ Por. tenże, Enarrationes in Ps. 138, 17, NBA 28, 484, PSP 42, 186; Špidlik - Gargano Grossi, Historia duchowości, t. 3, s. 363-364. Św. Augustyn (tamże) podkreśla przy tym, że dzięki owemu wewnętrznemu światłu Hiob zachowuje wobec ciemności nocy kuszenia, czyli utraty majątku oraz choroby, obojętność (indifferentia), z którą znosi wszystkie spotykające go nieszczęścia. Przypomina ona w części stoicką apatheia, z tą jednak różnicą, iż według tej filozofii, jest to cnota, którą mędrzec wypracowuje w sobie, zaś w nauczaniu biskupa Hippony wydaje się ona być darem Bożej łaski. A. Eckmann (Symbol apostolski, s. 153) zauważa, że zdaniem biskupa Hippony apatheia w ścisłym sensie jest niemożliwa dla człowieka, który nie może nie doznawać żadnych uczuć, gdyż prowadziłoby to do wynaturzenia jego duszy.

${ }^{85}$ Por. Augustinus, Enarrationes in Ps. 30 (4), 12, NBA 25, 504, PSP 37, 268. Więcej o sumieniu w nauczaniu św. Augustyna zob. M. Terka, O sumieniu. Przyczynki do synejdezjologii św. Augustyna, w: Być człowiekiem. Interdyscyplinarny namyst nad fenomenem sumienia, red. R. Ceglarek - M. Sztaba, Częstochowa 2015, 159-194.

${ }^{86}$ Por. Augustinus, Enarrationes in Ps. 55, 20, NBA 26, 160, PSP 38, 363.

${ }^{87}$ Por. tenże, Contra Gaudentium I 30, 35, NBA 16/2, 484; tenże, Quaestionum in Heptateuchum 2, 74, PL 34, 623, tłum. J. Sulowski: Św. Augustyn, Problemy Heptateuchu, PSP 46/1, Warszawa 1990, 121-122; Zagórski, Commendavit nobis Dominus oves suas, s. 386-388. O tym poznaniu siebie dzięki Bożemu pozwoleniu na kuszenie pisze św. Augustyn (De civitate Dei XVI 32, CCL 48, 536, tłum. Kubicki, s. 630) również w kontekście próby, na jaką został wystawiony Abraham: „Nie każde kuszenie na przyganę zasługuje, ale też i na wdzięczność, mianowicie, kiedy jest ku doświadczeniu. I zazwyczaj nie może człowiek poznać swej wartości duchowej, jeśli nie upewni się co do swoich sił, nie słowem, lecz czynem, gdy go nagabywa pokusa. I kiedy w tym dar Boży pozna, uświęca się, utwierdza w łasce, a nie nadyma się czczą pychą".

${ }^{88}$ Por. Augustinus, De civitate Dei XIX 13, CCL 48, 679-680, tłum. Kubicki, s. 780-781; tamże I 10, CCL 47, 10-11, tłum. Kubicki, s. 32-33; tenże, Enarrationes in Ps. 144, 22, NBA 28, 720, PSP 42, 300; Jaśkiewicz, Św. Augustyn - poszukiwanie Boga, s. 159; Zagórski, Commendavit nobis Dominus oves suas, s. 387-388; Bochet, Cuore, ADE, s. 529-530; Terka, ,, Corpus diaboli”, s. 353.

${ }^{89}$ Por. Augustinus, Enarrationes in Ps. 97, 6, NBA 27, 408, PSP 40, 301. Św. Augustyn (De civitate Dei XVIII 47, CCL 48, 645, tłum. Kubicki, s. 744; tenże, Enarrationes in Ps. 55, 20, NBA 26, 158-160, PSP 38, 363-364; tamże 118 (12), 4, NBA 27, 1214, PSP 41, 259-260; tamże 118 (26), 4, 
tym więc polega swoista pedagogia Opatrzności Bożej - jak zauważa biskup Hippony - że Pan, odrywając serca swych świętych od spraw ziemskich, przygotowuje im niebo ${ }^{90}$.

Ukazanie istoty władzy szkodzenia w ramach pola, w którym spotykaja się ze sobą kuszenie diabelskie, plany Bożej Opatrzności oraz wybór dokonany przez Hioba, sprawia, że zaprezentowany wyżej konflikt pomiędzy tym, czego chce złych duch, a tym, na co tak naprawdę zgadza się Bóg, wyznacza obszar możliwego działania potestas nocendi. Dlatego też dla podjętej próby jej rekonstrukcji, opartej o analizę myśli św. Augustyna, nie wystarcza - jak się wydaje - określenie sposobów działania diabła, lecz rzeczą konieczną jest spojrzenie również na to, czego on nie może uczynić. Należy zatem postawić pytanie o granice władzy szkodzenia, a odpowiedź, ukazującą czynniki ograniczające ją, wydobyć z przedstawionych wyżej analiz jej funkcjonowania.

5. Granice potestas nocendi - próba podsumowania. Diabelska władza szkodzenia, widziana z perspektywy cierpiącego Hioba, może wydawać się przemożna i wprost nieograniczona. Przecież pozbawia go ona nie tylko majątku i dostatniego życia, lecz także całej rodziny oraz zdrowia. Zły duch może zatem zniszczyć człowieka, a nawet zapanować nad jego ciałem. Niemniej jednak biskup Hippony podkreśla wielokrotnie w swej interpretacji dziejów Hioba, że najwyższa władza należy jedynie do Boga. Już ten właśnie fakt jest istotnym świadectwem mówiącym o ograniczonym zasięgu diabelskiej chęci szkodzenia. Stąd też pierwszym czynnikiem określającym warunki graniczne mocy szkodzenia jest ontologiczny status diabła, który przecież nie jest niczym innym, jak tylko stworzeniem, a w związku z tym naturą zależną od woli Stwórcy. Co więcej, biskup Hippony podkreśla - jak wspomniano wyżej - że zły duch jest stworzeniem upadłym, czyli pozbawionym swego pierwotnego blasku i strąconym do więzienia - świata. Dlatego, chociaż jego władza może wydawać się ogromna, jest w rzeczywistości znacznie mniejsza niż ta, którą posiadał przed swoim buntem wobec Boga' ${ }^{91}$.

NBA 27, 1348, PSP 41, 319; tenże, Sermo 22A, CCL 41, 304; tenże, Adnotationes in Job 38, NBA 10/3, 156) mówi również o jeszcze innym wymiarze zwycięstwa Hioba nad pokusą diabelską. Dzięki swoje postawie zaufania Bogu do końca i we wszelkich okolicznościach życia, jest on wzorem i przykładem do naśladowania dla wszystkich ludzi, a zwłaszcza dla chrześcijan. Uczy on bowiem pokładania nadziei w Bogu, odwrócenia się od światowych marności, spoglądania na Chrystusa ukrzyżowanego, czy też spełniania dobrych uczynków nie dla uzyskania od Boga jakichś dóbr, bądź też dla próżnej chwały ludzkiej, lecz dla bezinteresownej miłości Boga. Zob. J.M. Roesli, Iob, w: Augustinus-Lexicon, vol. 3, s. 684; Mura, Introduzione, s. 34. To zagadnienie, choć ważne, nie wnosi jednak niczego nowego do poszukiwać istoty potestas nocendi, dlatego też nie znajdzie ono miejsca na szersze omówienie w niniejszym artykule.

${ }^{90}$ Por. Augustinus, Enarrationes in Ps. 85, 9, NBA 26, 1260, PSP 40, 96; tenże, Adnotationes in Job 38, NBA 10/3, 156; Eckmann, Przebóstwienie człowieka, s. 140-142.

${ }^{91}$ Por. Augustinus, Enarrationes in Ps. 103 (4), 9, NBA 27, 764-766, PSP 41, 65-66. Dlatego też św. Augustyn (Sermo 12, 1-3, CCL 41, 164-167; Adnotationes in Job 1, NBA 10/3, 42) zauważa, 
Skoro zatem władza złego ducha jako upadłego stworzenia nie może być równa mocy sprawczej Stwórcy i w związku z tym musi posiadać swoje źródło w Bogu, to znaczy, że kolejnym czynnikiem ograniczającym władzę diabelską jest wola Stwórcy. Ona bowiem nie tylko wymusza konieczność prośby o pozwolenie na kuszenie Hioba, lecz także wyznacza konkretne granice dla udzielonej władzy szkodzenia, które, choć są stopniowo poszerzane, to jednak zawsze bardzo konkretnie określone i zmuszające złego ducha do bezwzględnego wobec nich posłuszeństwa. Hippończyk zauważa, że biblijny przekaz mówi o pewnych kręgach potestas nocendi. Najpierw bowiem diabeł przychodzi do Boga jedynie z oskarżeniem i prośbą o władzę szkodzenia, potem otrzymuje ją lecz tylko odnośnie do rzeczy zewnętrznych, a następnie również w stosunku do ciała Hioba, ale nie może posunać się dalej, by zabrać mu ży$\mathrm{cie}^{92}$. W interpretacji tego faktu św. Augustyn stwierdza więc, że władza złego ducha zostaje wyrokiem Bożej Opatrzności i na mocy Boskiego pozwolenia ograniczona jedynie do spraw doczesnych i dotyczy tylko rzeczy najniższych (infima), lecz nie może dotknąć rzeczy największych i najwyższych (maxima et summa). Moc udzielona diabłu może zatem zabrać nawet życie doczesne, i tak - jak podkreśla biskup Hippony - podległe śmierci, lecz nie potrafi odebrać prawdziwego życia, które daje Bóg. Ponadto, należy zauważyć, że diabeł nie posiada także ostatecznej władzy nad ludzkim ciałem, ponieważ nawet jeśli je zabije, to nie potrafi przeszkodzić w jego przyszłym zmartwychwstaniu. Dlatego też Hippończyk, patrząc z tego punktu widzenia, określa moc diabła jako karę potępionego (poena damnati), a nie władzę zagniewanego (potestas irati), gdyż niczego on nie potrafi bez zezwolenia ${ }^{93}$. Stąd też pozwolenie złemu duchowi na szkodzenie jest nie tyle władzą, ile „związaniem” go (alligatio), rozumianym jako niepozwolenie mu na zastosowanie całkowitej siły pokusy (tota temptatio) ${ }^{94}$. Jego wola szkodzenia pozostaje na uwięzi. Dlatego też, chociaż podejmuje on wszelkie możliwe dla niego czynności, by osiagnąć założone przez siebie cele doprowadzenia Hioba do upadku, to jednak skutek jego działań jest zupełnie odwrotny do zamierzonego, gdyż zaplanowane zło, dzięki łasce Bożej, przeradza się w wielkie dobro skutkujące ściślejszym zjednoczeniem Hioba z Bogiem.

\footnotetext{
że diabeł wprawdzie przychodzi przed oblicze Boga, lecz z powodu swego upadku mając serce najnikczemniejsze i najbardziej grzeszne (sordidissimo et immundissimo), nie może Go widzieć, gdyż widzą Go tylko ci, którzy zachowują czyste serce (por. Mt 5, 8). Zob. Bianchi - Müller, Diabolus, w: Augustinus-Lexicon, vol. 2, s. 384-385; Bolis, L'idolatria in S. Agostino, s. 313-320.

${ }_{92}$ Por. Augustinus, Adnotationes in Job 1, NBA 10/3, 42; tenże, Enarrationes in Ps. 103 (4), 9 , NBA 27, 764-766, PSP 41, 65-66; tenże, Sermo 343, 10, PL 39, 1511.

${ }^{93}$ Por. tenże, Enarrationes in Ps. 26 (2), 5, NBA 25, 362, PSP 37, 201; tamże 96, 17, NBA 27, 372-374, PSP 40, 294-295; tenże, De civitate Dei XII 6, CCL 48, 360-361, tłum. Kubicki, s. 448; tenże, Adnotationes in Job 38, NBA 10/3, 154-156.

${ }^{94}$ Tenże, De civitate Dei XX 8, CCL 48, 713, tłum. Kubicki, s. 813; tenże, De diversis quaestionibus ad Simplicianum II 1, 4, PL 40, 131-132.
} 
Elementem odsłaniającym pewną bezradność diabła w jego chęci szkodzenia, jest również podejrzliwe oskarżenie, które kieruje on pod adresem Hioba. Świadczy ono bowiem nie tylko o zazdrości złego ducha i chęci zniszczenia sprawiedliwego człowieka, lecz również o niemocy uczynienia czegokolwiek, co mogłoby doprowadzić do potwierdzenia stawianych zarzutów. Diabeł może oskarżać, ale na tym kończy się jego działanie. Potrafi zazdrościć, lecz - co mocno akcentuje św. Augustyn - nie posiada mocy potępienia Hioba ${ }^{95}$.

Analizowana wyżej możliwość postawienia oskarżenia, która jawi się obecnie już tylko jako sposobność do zawistnych podejrzeń i zarzutów, jest świadectwem jeszcze innego ograniczenia diabelskiej mocy szkodzenia. Należy bowiem przypomnieć, że oskarżające podejrzenie opiera się na jakiejś niewiedzy co do tego, jak jest naprawdę. Dzieje się tak dlatego, że - jak zaznaczono wyżej - zły duch nie ma dostępu do ludzkiego serca i nigdy nie zdoła go przeniknąc (penetrare non potuit in cor) ${ }^{96}$. Pozostaje więc ono poza granicami udzielonej mu władzy. Podejrzliwość diabelska musi więc jedynie oskarżać, by uzyskując pozwolenie na doświadczenie Hioba, czyli niejako na sprawdzenie słuszności stawianych mu zarzutów, podjąć próbę doprowadzenia go do opisanego wyżej grzesznego upadku. Próba Hioba wydaje się więc być również próbą dla złego ducha, bo również on nie może znać jej wyniku.

Istnienie pokusy diabelskiej oznacza jednak tylko tyle, że nie ma ona możliwości zmuszenia kuszonego do przyjęcia jej. Diabeł nie ma więc wpływu na wolną wolę człowieka ${ }^{97}$. Wobec tego może on tylko oczekiwać w niepewności oddziałując jedynie na okoliczności zewnętrzne w konkretnych życiowych sytuacjach, w jakich aktualnie znajduje się człowiek. To zatem wolność Hioba jest kolejnym czynnikiem ograniczającym diabelską wolę szkodzenia. Dlatego też św. Augustyn stwierdza, że w rzeczywistości to nie diabeł panuje nad człowiekiem sprawiedliwym, lecz człowiek nad diabłem, posiadając władzę nad demoniczną żądzą szkodzenia ${ }^{98}$.

Wydaje się, że kwintesencją i niejako symbolem ograniczonej tak wieloma czynnikami diabelskiej woli szkodzenia, jest jej rola narzędzia w rękach

\footnotetext{
${ }^{95}$ Por. tenże, Enarrationes in Ps. 34 (1), 7, NBA 25, 678, PSP 37, 355.

${ }^{96}$ Por. tamże 103 (4), 7, NBA 27, 760, PSP 41, 63; tenże, Sermo 12, 6, CCL 41, 169.

${ }^{97}$ Por. tenże, Enarrationes in PS. 55, 19, NBA 26, 158, PSP 38, 362.

${ }^{98}$ Wydaje się jednak, że św. Augustyn mówi tutaj przede wszystkim o człowieku sprawiedliwym, a zatem niekoniecznie musi mieć ta teza zastosowanie do ludzi pogrążonych w grzechu i przez niego odłączonych od Boga. Chociaż bowiem w tym przypadku diabeł nie posiada możliwości wglądu w ludzkie serce, to jednak sam biskup Hippony pisze na innym miejscu (Enarrationes. in Ps. 141, 14, NBA 28, 608, PSP 42, 244) o procesie opanowania człowieka przez złego ducha, który to proces określa mianem zniszczenia serca (ruina cordis). Wprawdzie wydaje się to być proces w jakimś stopniu dobrowolnego oddania się człowieka w niewolę diabła poprzez wybór grzechu, a przez niego obywatelstwa w królestwie diabła określonym przez Hippończyka symboliczną nazwą Babilonu, to przecież nie zmienia to faktu jakiegoś zniewolenia, które dokonuje się, gdy człowiek trwa w swym odwróceniu się od Boga. Por. tenże, Adnotationes in Job 20, NBA 10/3, 92-94; Terka, ,, Corpus diaboli”, s. 352-353.
} 
Boga, które bezwiednie, a nawet wbrew woli, realizuje plany Bożej Opatrzności. W nim bowiem jak w soczewce skupia się zarówno to, co diabeł może wykonać, by zaszkodzić Hiobowi, jak i to, czego zrobić nie może. Władza szkodzenia widziana z tej perspektywy, przestaje być czymś strasznym i nieprzewidywalnym dla człowieka wiernego Bogu, a staje się zwyczajnym elementem, trudnej wprawdzie i niebezpiecznej, lecz pewnej drogi do świętości i wiecznego zbawienia, na której rzeczą istotniejszą od cierpień i utrapień jest ufność w Boże miłosierdzie. Dzięki niej bowiem zarówno Hiob, jak sam św. Augustyn, znajdują moc, by wytrwać przy Bogu i odnaleźć głębszy sens w tym, co człowiek musi znosić w czasie swego ziemskiego życia.

$* * *$

Podsumowując powyższe rozważania należy zauważyć, że postawione na ich początku pytanie o istotę oraz warunki możliwości zaistnienia diabelskiej potestas nocendi, dają się określić i nieco wyjaśnić w polu zakreślonym przez wzajemne relacje i oddziaływanie na siebie Boga, diabła i Hioba. Dzięki temu pierwsza scena dramatu opisanego na kartach omawianej księgi biblijnej, znajduje swe wyjaśnienie w tym, co rozgrywa się na scenie drugiej, zaś druga pozwala odkryć swój sens w wydarzeniach sceny pierwszej.

Relację diabła do Boga opisuje prowokacja, jakiej dopuszcza się zły duch, oskarżając Hioba, zaś stosunek Boga do diabła odsłania się najpierw w zgodzie na szkodzenie, czyli w udzieleniu mocy do działania diabelskiej chęci szkodzenia, a następnie w roli narzędzia, do której nieprzyjaciel rodzaju ludzkiego zostaje sprowadzony i użyty, a w końcu dzięki niej przezwyciężony. Z kolei jego stosunek do Hioba określają takie terminy jak: oskarżenie, podejrzenie, zazdrość oraz kuszenie. Odpowiedzią Hioba, opisująca jego relację do diabła jest $\mathrm{w}$ zasadzie brak wyraźnego i konkretnego odniesienia. Bohater zdaje się bowiem pomijać rolę diabła, dostrzegając w swej niedoli rękę Boga i nie zgadzając się na pokusy podsuwane przez złego ducha. Relację Boga do Hioba biskup Hippony opisuje zaś głównie przez pojęcie próby, udoskonalenia i objawienia ukrytej sprawiedliwości, a stosunek Hioba do swego Stwórcy oddaje jako zaufanie Bożej Opatrzności oraz uzgodnienie swej woli z Jego wolą.

Interpretacja, jakiej poddaje św. Augustyn pierwsze dwa rozdziały biblijnej Księgi Hioba, ukazuje więc przede wszystkim moc i dobroć Boga, który posługuje się diabłem, by uświęcić swego wiernego sługę, a następnie właściwą niemoc złego ducha, którego potestas nocendi zależy zarówno od woli Boga, jak i wyboru kuszonego człowieka. Istotne znaczenie ogrywa w niej również postać głównego bohatera jako wzoru wiernego oddania się Bogu nawet w najtrudniejszych sytuacjach życia.

Ogólną wymowę komentarzy biskupa Hippony wyjaśniających istotę władzy szkodzenia można więc uznać za pozytywną, a nawet optymistyczna. Choć bowiem człowiek, chcąc iść drogą wyznaczoną przez Boga, nie uniknie 
cierpień i różnego rodzaju trudności, to jednak nie są one czymś, co ma na celu zniszczenie go, lecz raczej tym, co może go udoskonalić i umocnić w świętości. Tutaj więc ujawnia się najwyraźniej paradoks Augustyńskiej interpretacji dziejów Hioba, który mówi, że diabeł, używany i wykorzystywany przez Boga jako Jego narzędzie, jest istotnym elementem procesu duchowego wzrostu człowieka, a samego złego ducha ustawia niejako w roli bezwiednego formatora sługi Bożego. Takie ujęcie dramatu Hioba zachęca zatem do ufności, której źródłem - zdaniem św. Augustyn - jest wiara w to, że nad diabelską mocą szkodzenia czuwa nieustannie Boża Opatrzność.

\section{POTESTAS NOCENDI IN THE LIGHT OF ST. AUGUSTINE'S COMMENTARY TO THE BOOK OF JOB 1-2}

\section{(Summary)}

St. Augustine interprets the tragedy of Job presented in the Bible by two coincidental and connected with each other scenes: the first describes the history of man depressed with suffering, who lost his property, family and health, where the second one shows the dialog on the spiritual level between God and Satan, in consequence of which Satan receives the power of doing damage (potestas nocendi) to Job. The matter of this power, its range and goal are examined by The Bishop of Hippo by means of the relationship analysis between God, deviland Job.

The power of harming comes from God and He is definitely responsible for Job's suffering. He gives this power for devil but only for making man more prefect and revealing His justice. Where the action of devil is the charge of insincere devotion, jealousy, suspecting of hidden sin and temptation of Job in order to make him turn around from God. But for Job the experience of suffering is the trial which is given from God and by it God demands from Job taking a decision. His reply to God is described by St. Augustine as trust and agreement his will with God's will. The power of harming is limited first by God's will and permission given by Him, next by devil's nature as a creature which has to ask for harming permission and hasn't got any access to human heart, and later by Job's will and a choice made by him. So potestas nocendi is not license of devil, but first of all the power of God and devil's desire of harming.

Key words: God, devil, Job, temptation, Providence, accusing, suspicion, permission, trial, justice, free will, the power of harming.

Słowa kluczowe: Bóg, diabeł, Hiob, kuszenie, Opatrzność Boża, oskarżenie, podejrzenie, pozwolenie, próba, sprawiedliwość, wolna wola, władza szkodzenia. 


\section{BIBLIOGRAFIA}

\section{Źródła}

Augustinus, Adnotationes in Job liber unus, NBA 10/3, ed. G. Mura - V. Tarulli, Roma 1999, 42-193.

Augustinus, Contra Cresconium grammaticum partis Donati libri quattuor, PL 43, 445-594.

Augustinus, Contra Gaudentium donatistarum episcopum libri duo, ed. E. Cavallari, NBA 16/2, Roma 2000, 430-551.

Augustinus, Contra Iulianum libri sex, PL 44, 641-874, thum. W. Eborowicz: Św. Augustyn, Przeciw Julianowi, PSP 19, z. 1-2, Warszawa 1977.

Augustinus, De civitate Dei libri viginti duo, CCL 47-48, ed. B. Dombard - A. Kalb, Turnholti 1955, tłum. W. Kubicki: Św. Augustyn, Państwo Boże, Kęty 2002.

Augustinus, De diversis quaestionibus ad Simplicianum libri duo, PL 40, 102-148.

Augustinus, De divinatione daemonum liber unus, PL 40, 581-592.

Augustinus, Enarrationes in Psalmos 1-50, NBA 25, ed. A. Corticelli, Roma 1967; Enarrationes in Psalmos 51-85, NBA 26, ed. V. Tarulli, Roma 1970; Enarrationes in Psalmos 86-120, NBA 27, ed. T. Mariucci - V. Tarulli, Roma 1976; Enarrationes in Psalmos 121-150, NBA 28, ed. V. Tarulli, Roma 1977, tłum. J. Sulowski: Św. Augustyn, Objaśnienia Psalmów, PSP 37-42, Warszawa 1986.

Augustinus, Epistulae, PL 33, 61-1094.

Augustinus, De Genesi ad litteram libri duodecim, ed. L. Carrozzi, NBA 9/2, Roma 1989, 12-727, tłum. J. Sulowski: Św. Augustyn, Komentarz słowny do Ksiegi Rodzaju, w: Św. Augustyn, Pisma egzegetyczne przeciw manichejczykom, PSP 25, Warszawa 1980, 113-382.

Augustinus, In epistulam Iohannis ad Parthos tractatus decem, ed. G. Madurini - L. Muscolino, NBA 24/2, Roma 1968, 1636-1855; thum. W. Szołdrski - W. Kania: św. Augustyn, Homilie na Pierwszy list św. Jana, w: Św. Augustyn, Homilie na Ewangelie i Pierwszy list św. Jana, PSP 15/2, Warszawa 1977, 381-502.

Augustinus, In Iohannis evangelium tractatus CXXIV, CCL 36, ed. R. Willems, Turnholti 1954, , tłum. W. Szołdrski - W. Kania: Św. Augustyn, Homilie na Ewangelie i Pierwszy list św. Jana, PSP 15, z. 1, Warszawa 1977, z. 2. Warszawa 1997, 9-379.

Augustinus, De patientia, PL 40, 611-626.

Augustinus, De sermone Domini in monte libri duo, PL 34, 1229-1308.

Augustinus, De Trinitate libri quindecim, ed. A. Trapè - M.F. Sciacca, NBA 4, Roma 2003, tłum. M. Stokowska: Św. Augustyn, O Trójcy Świętej, POK 25, Poznań - Warszawa - Lublin 1962.

Augustinus, Quaestionum in Heptateuchum libri septem, PL 34, 547-824, thum. J. Sulowski: Św. Augustyn, Problemy Heptateuchu, PSP 46/1, Warszawa 1990.

Augustinus, Sermones de Vetere Testamento 1-50, CCL 41, ed. C. Lambot, Turnholti 1961.

\section{Opracowania}

Bianchi C. - Müller Ch., Diabolus, w: Augustinus-Lexicon, hrsg. C. Mayer-A.E.J. Grotte, vol. 2, Basel 1996-2002, 382-396.

Bochet I., Cuore, w: Agostino Dizionario Enciclopedico, ed. A. Fitzgerald, ed. italiana L. Alici - A. Pieretti, Roma 2007, 524-534.

Bolis G., L'idolatria in S. Agostino. Una prospettiva antropologica, Roma 2004. 
Brugarolas M., Księga Hioba wedtug Grzegorza z Nyssy, tłum. A. Machowski, BPTh 6 (2013) 149-165.

Cipriani N., Molti e uno solo in Cristo. La spiritualità di Agostino, Roma 2009.

Clark M.T., Mondo, w: Agostino Dizionario Enciclopedico, ed. A. Fitzgerald, ed. italiana L. Alici - A. Pieretti, Roma 2007, 964-967.

Dıuth M., Volontà, w: Agostino Dizionario Enciclopedico, ed. A. Fitzgerald, ed. italiana L. Alici - A. Pieretti, Roma 2007, 1460-1466.

EcKmann A., Przebóstwienie człowieka w pismach wczesnochrześcijańskich, Lublin 2003.

EcKmann A., Symbol apostolski w pismach świętego Augustyna, Lublin 1999.

Fleteren F. van, Demoni, w: Agostino Dizionario Enciclopedico, ed. A. Fitzgerald, ed. italiana L. Alici - A. Pieretti, Roma 2007, 539-541.

Fleteren F. van, Diavolo, w: Agostino Dizionario Enciclopedico, ed. A. Fitzgerald, ed. italiana L. Alici - A. Pieretti, Roma 2007, 554-555.

Häring H., Malum, w: Augustinus-Lexicon, hrsg. C. Mayer - A.E.J. Grotte, vol. 3, Basel 2004-2010, 1111-1121.

I conflitti religiosi nella scena pubblica, t. 1: Agostino a confronto con manichei e donatisti, ed. L. Alici, Roma 2015.

IsetTa S., Libro XI del „De civitate Dei”, w: Lettura del „,De civitate Dei” libri XI-XVI, Roma $2009=$ SEA 115 (2009) 7-54.

JAŚKIEwICz S., Św. Augustyn - poszukiwanie Boga, Katowice 2012.

Jóźwiak M., „,Komentarz do historii Hioba” Filipa Prezbitera a epistoma tego dzieła. Przyczynek do badań porównawczych nad tymi tekstami, VoxP 34 (2014) t. 62, 185-195.

KowalczyK S., Człowiek i Bóg w nauce św. Augustyna, Lublin 2007.

MeEr F. van der, Augustinus der Seelsorgen. Leben und Wirken eines Kirchenväters, Köhln 1951.

Mura G., Introduzione, w: Sant'Agostino, Opere esegetiche, ed. G. Mura - V. Tarulli, NBA 10/3, Roma 1999, 27-36.

NieŚCIOR L., Cierpienie sprawiedliwego w Komentarzu do Księgi Hioba św. Jana Chryzostoma, WPT 16 (2008) nr 1, 211-230.

PACzKowski M.C., Reinterpretacja postaci Hioba $w$ starożytnym monastycyzmie chrześcijańskim, BPTh 6 (2013) 179-203.

Pagliacci D., Male e peccato: „,De civitate Dei” XVI. Riflessi antropologici, w: Il mistero del male e la libertá possibile (III): Lettuta del „De civitate Dei” di Agostino, ed. L. Alici - R. Piccolomini - A. Pieretti, Roma 1996 = SEA 54 (1996) 191-206.

Pieretti A., Agostino e l'origine del male, w: I conflitti religiosi nella scena pubblica, t. 1: Agostino a confronto con manichei e donatisti, ed. L. Alici, Roma 2015, 57-82.

Pierini A., Agostino e l'impegno nella lotta contro il male, w: I conflitti religiosi nella scena pubblica, t. 1: Agostino a confronto con manichei e donatisti, ed. L. Alici, Roma 2015, 83-104.

Roesti J.M., Iob, w: Augustinus-Lexicon, hrsg. C. Mayer - A.E.J. Grotte, vol. 3, Basel 2004-2010, 684.

Silva M.F di, Agostino e il problema del negativo pluralità e unità delll'identità di male e nulla, w: I conflitti religiosi nella scena pubblica, t. 1: Agostino a confronto con manichei e donatisti, ed. L. Alici, Roma 2015, 105-118.

Š́pidlik T. - Gargano I. - Grossi V., Historia duchowości, t. 3: Duchowość Ojców Kościoła, tłum. K. Stopa, Kraków 2004.

Steinhauser K.B., Adnotationes in Job, w: Agostino Dizionario Enciclopedico, ed. A. Fitzgerald, ed. italiana L. Alici - A. Pieretti, Roma 2007, 114-115. 
Terka M., „Corpus diaboli”, czyli duchowe podtoże prześladowań Kościoła w świetle „Enarrationes in Psalmos” św. Augustyna, w: Być w sercu Kościoła. Księga jubileuszowa z okazji 25 lecia pracy naukowej ks. dr. hab. Mariana Dudy, red. S. Jasionek, Częstochowa 2014, 343-357.

Terka M., O sumieniu. Przyczynki do synejdezjologii św. Augustyna, w: Być człowiekiem. Interdyscyplinarny namyst nad fenomenem sumienia, red. R. Ceglarek - M. Sztaba, Częstochowa 2015, 159-194.

Terka M., Źli chrześcijanie w Kościele w świetle nauczania św. Augustyna, VoxP 33 (2013) t. 60, 417-448.

ZagóRski D., Commendavit nobis Dominus oves suas. Pasterska troska o wiernych w świetle „Sermones” św. Augustyna, Toruń - Pelplin 2013.

\section{Pomoce}

Agostino Dizionario Enciclopedico, ed. A Fitzgerald, ed. italiana L. Alici - A. Pieretti, Roma 2007.

Augustinus-Lexicon, hrsg. C. Mayer et al., hrsg. K.H. Chelius - A.E.J. Grote, vol. 1/1-2: A-Ani, Basel - Stuttgart 1986; 1/3: An-Asi, Basel - Stuttgart 1988; 1/4: As-Be, Basel - Stuttgart 1990; 1/5-6: Be-Ciu, Basel - Stuttgart 1992; 1/7-8: Ciu-Con, Basel - Stuttgart 1994; vol. 2/1-2: Cor-De, Basel - Stuttgart 1996; 2-3-4: De-Do, Basel - Stuttgart 1999; 2/5-6: Do-Ep, Basel - Stuttgart 2001; 2/7-8: Ep-Fi, Basel - Stuttgart 2002; vol. 3/1-2: Fi-Hie, Basel - Stuttgart 2004; 3/3-4: Hie-Inst, Basel - Stuttgart 2006.

Słownik łacińsko-polski, t. 1-5, red. M. Plezia, Warszawa 1998.

The Oxford Guide to the historical Reception of Augustine, ed. K. Pollmann, vol. 1, Oxford 2013. 
